\title{
Organizational ambidexterity: a critical review and development of a project focused definition
}

\section{Yacoub Petro, PhD (yacoub.petro@stantec.com; yacoub_petro@hotmail.com)}

Director of Project Management, MWH now part of Stantec, Office 504 Core F, Al Sahaa Offices-BDubai, United Arab Emirates.

Udechukwu Ojiako, LLB (Lond) (udechukwu.ojiako@outlook.com)

Professor of Engineering Management \& Law, University of Sharjah, Sharjah 27272 United Arab Emirates.

Visiting Professor of Management, The Risk Institute, University of Hull, University of Hull, Hull HU6 7RX, United Kingdom.

Visiting Professor of Business, UNIZIK Business School, Nnamdi Azikiwe University, Awka - Nigeria.

Terry Williams, PhD (terry.williams@hull.ac.uk)

Professor of Management Science; Director, The Risk Institute, University of Hull, Hull HU6 7RX, United Kingdom.

Alasdair Marshall, PhD (a.marshall@soton.ac.uk)

Lecturer in Risk Management, University of Southampton, 1 University Road, Southampton SO17 1BJ, United Kingdom.

\begin{abstract}
The objective of this paper is to explore a project-focused understanding of contemporary organisational ambidexterity literature. As part of this process, a taxonomical analysis of the elements and components of the concept of organisational ambidexterity is undertaken. Findings suggest that a project-focused notion of organisational ambidexterity involves different levels, dimensions and mechanisms. The predominant contribution of this paper resides within the taxonomy study, which provides a platform for a more holistic understanding of organisational ambidexterity as a multifaceted concept applicable to the project management discipline.
\end{abstract}

\section{Introduction}

\section{What is organisational ambidexterity?}

The notion of organisational ambidexterity generally refers to a variety of organization competencies which allows the organisation in question to undertake two contradictory activities simultaneously. Organisational ambidexterity however differs from the notion of dynamic capabilities or organizational 
flexibility which has been discussed extensively within the "management in engineering" domain (see for example, Lim et al., 2011; Ansari et al., 2014). Organizational ambidexterity focuses on "....the ability to simultaneously pursue both incremental and discontinuous innovation and change [which] results from hosting multiple contradictory structures, processes, and cultures within the same firm" (Tushman and O'Reilly, 1996; p. 24). On the other hand 'dynamic capabilities' refers to key competitive attributes that manifest in an organisation's ability to remain competitive in high velocity markets through its ability to sense, seize and reconfigure its processes (Choi et al., 2018a). The implications are that organizational ambidexterity represents a mediating factor in the link between the dynamic capabilities of an organisation and its competitiveness (Wei et al., 2014; Jurksiene and Pundziene, 2016).

Over the years, a number of different scholars have advanced varying definitions of organisational ambidexterity. Simsek (2009) provides a comprehensive review of these various literatures which suggests that at the core of the notion of organisational ambidexterity resides the tensions experienced by organisations simultaneously seeking to maintain a balance between two contradictory analytical constructs, namely exploitation and exploration. The literature has been quite clear that both analytical constructs of organisational ambidexterity require distinct (different) organizational routines and competencies. In the case of exploitation, this will be internal consistency and control (Benner and Tushman, 2003). On the other hand, in the case of exploration, the focus is likely to be on risk-taking and flexibility (McGrath, 2001). Studies have found that an emphasis by an organization on one can degrade the other (Jansen et al., 2009), so ambidexterity emphasises a trade-off balance between these two constructs (Adler et al., 1999). It is noted that while the paper focuses on 'organisational ambidexterity', for brevity, we however utilize 'organisational ambidexterity' and 'ambidexterity' interchangeably.

\section{Articulation and placement}

As an emergent research concept (Raisch and Birkinshaw, 2008; Simsek, 2009), organisational ambidexterity has increasingly attracted the attention of academic scholarship in various disciplines. This has ranged from operations (Chandrasekaran et al., 2012) and project management (Aubry and Lièvre, 2010; Leybourne and Sainter, 2012; Eriksson, 2013; Pellegrinelli et al., 2015; Turner and Lee-Kelley, 2013; Turner et al., 2013a, 2013b, 2014, 2015, 2016), to technology innovation and engineering management studies (Lin and McDonough, 2011; Liu and Leitner, 2012; Liu et al., 2012). In addition, there has also been studies exploring the impact of ambidexterity on specific organizational attributes such as dynamic capabilities (O'Reilly and Tushman, 2013), knowledge management (Im and Rai, 2008) 
and leadership (Nemanich and Vera, 2009). Other studies have also explored the relationship between ambidexterity and organizational change (Tushman and O'Reilly, 1996) and ambidexterity and firm performance (Kristal et al., 2010). Thus, it is reasonable to suggest that the concept of ambidexterity is pervasive, a point reiterated by Birkinshaw and Gupta (2013) and Turner et al. (2013a) in their etiolation of the versatility (and appeal) of ambidexterity among scholars. Although being the case, there appears to be sparse research on ambidexterity situated firmly within the "management in engineering" domain. For example, no publications on ambidexterity were found in well-respected engineering management journals such as ASCE Journal of Management in Engineering, ASCE Journal of Construction Engineering and Management, Engineering Project Organization Journal and Engineering Management Journal. Six such research papers have been published on ambidexterity in IEEE Transactions on Engineering Management and one published in Construction Management and Economics. Furthermore, studies (Lynn, 2002; Shaw, 2002; Picon, 2004; Sousa-Poza and Kovacic, 2008) that have examined the agenda for engineering management research appear not to have expressed substantial interest on the topic, thus the intended contribution of our study.

\section{Our contributions and research question}

Our study intends to make distinct contributions to project and engineering management scholarship. The literature suggests that the transient nature (Turner et al., 2015) and the mutual interdependence of the process elements within projects (Turner and Lee-Kelley, 2013) makes them ideal for the duality associated with ambidexterity. Three reasons have been advanced in the literature. Firstly, projects are primarily focused on long-term transformation of scarce resources. This transformation process is however constantly experiencing tensions emanating from a desire for instrumentality (processes and methodologies) on one hand as against a need for flexibility required which reinforces our notion of doing routine versus non-routine projects. Secondly, projects are characterised by their transient nature. Thirdly, the process elements within projects are characterised by mutual interdependence. It is therefore within this context that we explored a much needed specific definition of ambidexterity that was contextualised within projects. The basis of such a study involved a systematic literature review, which allowed a taxonomical analysis of the elements and components of a project-focused notion of ambidexterity to be undertaken. This is the main contribution of this study to the "management in engineering" body of knowledge. However, when projects focus almost exclusively on the exploration of new innovative solutions, the potential for overruns (leading to failure) become more likely (Liu et al., 2012), requiring for its mitigation engagement with risk forecasting and intelligence (Marshall et al., 
2018). Conversely, projects that focus almost exclusively on exploiting existing capabilities through exemplifying efficiencies in their routines and minimising risks are likely to become unable to support non-routine project work which is characteristic of the current global engineering environment. A further challenge associated with a focus on exploitation is that the classical control notion of project instrumentality is unlikely to sustain high levels of learning (Lee et al., 2013), task uncertainty and leadership (Lin and McDonough, 2011) and the demand for innovation associated with most complex engineering projects (Lin and McDonough, 2011; Liu and Leitner, 2012; Liu et al., 2012; Chiu, 2014; Choi and Phan, 2014; Chen and Liu, 2018; Choi et al., 2018b). The need to simultaneously balance exploration (of innovation) and exploitation (of current and existing capabilities) is a typical challenge faced by most engineering endeavours and projects (Liu et al., 2012; Du et al., 2013) and this challenge creates the need for the project and engineering management community to understanding contemporary organisational ambidexterity literature. This is because any focus of such projects predominantly on exploitation is likely to lead to "success trap" (Levinthal and March, 1993, p.106) while on the other hand, an over-emphasis on exploration will likely to lead to an ever ending "cycle of failure" (Levinthal and March, 1993, p.105); in effect, a failure trap. Thus, in light of ideas relating to 'project studies' and the need for "fostering vibrant dialogue and debate" (Geraldi and Soderlund, 2018; p. 55) among project and engineering management scholars and practitioners, this paper endeavours to engage in discourse likely to facilitate (i) greater understanding of organisational ambidexterity applicable to projects and by implication contribute to the management in engineering discourse (Evans and Bredin, 1987; Kotnour and Farr, 2005; Omurtag, 2009; Cerchione et al., 2016) and (ii) design transient organisational and learning networks, structures and processes that are capable of effectively supporting organisational ambidexterity in their project environments.

We posit that organisational ambidexterity is largely theoretically constructed and therefore may be perceived by the project management discipline which is increasingly highly institutionalized and driven by practice (Lenfle and Loch, 2010) as of little or no relevance. As Birkinshaw and Gupta (2013) point out, organisational ambidexterity is not a term used by practicing managers. Neither do we contend that it is a term used in project management practice. Certainly, it is not a term that appears in either the 2012 APM Body of Knowledge ( $6^{\text {th }}$ edition) or the 2017 Project Management Institute (PMI) Body of Knowledge (6 ${ }^{\text {th }}$ edition). It also does not appear in the 2012 Definitions handbook for the 2012 Association for Project Management (APM) Body of Knowledge (6th Edition).

Recent studies on ambidexterity within the context of project management suggests the widely accepted importance in the use of projects to contextualise ambidexterity (Turner et al., 2013a, 2013b, 
2014, 2015, 2016; Pellegrinelli et al., 2015; Bednarek et al., 2016; Petro, 2017). Drawing from earlier works of Birkinshaw and Gupta (2013) who had argued that organisations were more efficient than markets in long-term transformation of scarce resources, we posit that projects encompass the very essence of this transformation process and associated tensions which exist between the misguided desire for instrumentality (Lenfle and Loch, 2010) and the flexibility required to deal with the uncertainties which prevail in projects due to their novelty (Prado and Sapsed, 2016). From Andriopoulos and Lewis (2009) therefore, we argue that project represent the most efficient approach to balance competing short (exploitation) and long term (exploration) demands that organisations face. While the majority of engineering endeavours are increasingly being organized and implemented as projects (Kuprenas et al., 1999), there is a view in the literature that the temporary nature of projects may hinder not only their efficiencies, but also the achievement of strategic business imperatives driving these projects (Bakker et al., 2016; Ligthart et al., 2016).

In effect, since project-based working is the dominant form of organising in contemporary organisations which rely heavily on exploitation and exploration (Liu and Leitner 2012), it will be expected that both exploitation and exploration would be readily identifiable within a project context and projects therefore remain a viable way to contextualise ambidexterity. However, this perspective does not necessarily appear to be widely shared. In fact Aubry and Lièvre (2010) claims that the challenges of project-laden context of ambidexterity is that while projects tend to reflect exploration, project management (in effect, the process of project delivery, which is increasingly standardized) emphasises more of exploitation mode. This is demonstrated by the emphasis of project management frameworks and standards on risk minimization (Pellegrinelli et al., 2015; Turner et al., 2015). In effect, both Pellegrinelli et al. (2015) and Turner et al. (2015) align with espoused duality debates in ambidexterity literature between efficiency versus flexibility and adaptability versus alignment. It is perhaps for this reason that the ambidexterity challenge has been predominantly articulated at the business and organisational level (Markides, 2013).

\section{The context and project managements view of ambidexterity}

We had argued that prior works of scholarship have not provided a comprehensive and cohesive review of literature on ambidexterity that is explicitly contextualised within the context of project management. We briefly review the literature that points to the unfocused nature of work on ambidexterity in project management. We claim that the less than eloquent development of organisational ambidexterity literature 
contextualised within project management presents a considerable opportunity for multilevel exploration and review of the literature to be brought to the attention of project management scholars.

Lee et al. (2006) examined ambidextrous coping strategies in projects finding a more positive impact of such strategies on larger and globally distributed projects than smaller sized projects. Of particular relevance is that their findings focused on extending agile approaches to project delivery to emphasise the duality of ambidexterity. In Aubry and Lièvre (2010) and also later Lin and McDonough (2011), the role of leadership in fostering ambidexterity was examined with Aubry and Lièvre (2010) drawing from exploitation which focuses on existing leadership competences and exploration learning modes to examine the tensions between different forms of action that can be adopted by project managers. Hoang and Rothaermel (2010) examined the impact of external exploration and exploitation on project performance from an alliance activity perspective, finding that alliance exploitation positively influenced project performance, while alliance exploration impacted negatively on project performance. Using an in-depth case study, Liu and Leitner (2012) emphasised the need for a balanced countenance of ambidexterity's two contradictory analytical constructs if projects were to succeed. Most importantly, they found that structural separation was generally ineffective because of the constant cycling between exploration and exploitation in projects. Liu et al. (2012) examined ambidexterity in complex construction engineering projects construction projects finding evidence of considerable challenges due to the need for a variety of organizational-level support required for its two analytical constructs. Citing the fragmented nature of construction projects (and ensuring structural separation), they suggested the need to create two distinct operational units - each focused on an individual construct of ambidexterity as the most efficient way of managing ambidexterity in construction projects.

Eriksson (2013) suggested that their temporary and short-term nature made projects more attune to exploitation than to exploration. He however pointed out that due to the limitations of sequential and structural separation of its two constructs, ambidexterity should be managed differently at the project, project portfolio and business unit level. Pellegrinelli et al. (2015) however addressing similar questions as Liu et al. (2012) thought it best to facilitate ambidexterity through the flexible but complementary use of projects and programs.

Other recent studies on project-contextualised ambidexterity includes that of Leybourne and Sainter (2012). In their study, they recommended the need for more robust exploration of ambidexterity in light of tensions that exist when considering on one hand, the desire for novelty and improvisation as against on the other hand, the desire for projects to be controlled. In efforts to enhance the use of projectportfolio management (PPM) as a "specific managerial actions that facilitate the simultaneous pursuit of 
exploitation and exploration" (O'Reilly and Tushman 2011, p. 8), Turner et al. (2013a) undertook a systematic review of literature focused on understanding ambidexterity mechanisms. This study was slightly extended in Turner et al. (2013b) with the focus on understanding how ambidexterity could be enacted at the individual level, in order words, the level of the implementing project manager. The main findings of this study were that critical resources of ambidexterity resources were connected in a manner that suggests that a project-focused form of ambidexterity was perhaps more complex than is being acknowledged in project management works of scholarship. Turner et al. $(2013 \mathrm{a}, \mathrm{b})$ were further extended in Turner et al. (2014), where a practical analytical framework for project-based ambidexterity was developed to facilitate multi-level understanding of how ambidexterity may be operationalized. In Turner et al (2015), an empirical (qualitative) study was employed in an attempt to articulate how ambidexterity may best be delivered in project settings. Five different managerial actions characteristic of the individual level of the implementing project manager were found. While contributing to the emerging literature on ambidexterity, our study seeks to organize the different scholarly contributions on this subject in order to undertake a taxonomical analysis of the elements and components of the concept. Turner et al (2015) was extended in Turner et al. (2016) where two distinct project-based forms that led to the enactment of organisational ambidexterity were identified.

Although the study by Turner et al (2013a) produced mechanisms for achieving ambidexterity in organizations, they indicated that there still remains a lack of understanding as to their applicability. Managers on the other hand may not be able to "orchestrate" exploitation and exploration without a proper understanding for all the underlying constituents of ambidexterity, its applications, and its mechanisms. From this review, it is safe to suggest that detailed understanding of how ambidexterity can be contextualised within projects remain far from clear. However, we deduce from temporality project literature (Prado and Sapsed, 2016) and much wider temporality literature in organisation studies (Bakker et al,. 2016) that the enactment of organisational ambidexterity within a project context may encompass the need for project teams to temporally switch between exploitation and exploration, an idea derived from temporal switching capabilities first discussed in Gupta et al. (2006).

To sum up, the main challenge in exploring a project-driven notion of ambidexterity relates to the question of the dominance of standards and bodies of knowledge in projects (Morris et al., 2006). This we argue from an overview of the literature will support the exploitation analytical construct of ambidexterity. However, the dominance of standards and bodies of knowledge in projects is much criticised. Projects also involve an element of uniqueness and novelty which suggests a simultaneous emphasis on the exploration analytical construct of ambidexterity. In effect, both analytical constructs of 
ambidexterity, namely exploitation and exploration, are arguably likely to present in most projects (Liu and Leitner, 2012). In sum, projects are also seen in the literature as an appropriate means of managing the associated tensions within the ambidexterity constructs of exploitation and exploration.

Taking all the above into consideration, this study is particularly interested in exploring the contemporary elements and components underpinning a project-focused perspective of organisational ambidexterity literature. Thus, we present our research question as:

What is a project management focused definition of ambidexterity taking note of the evolution of organizational ambidexterity literature?

Since we intend to advance a more specified definition of ambidexterity which is contextualised within projects and their managing organizations, associated taxonomical analysis of the elements and components of the concept will be undertaken from a predominantly project perspective (Stingl and Geraldi, 2017). Undertaking such a review of literature reflects our acknowledgement that such reviews serve as an effective means of capturing different and emerging considerations in theoretical concepts. Rowe (2014) claims that this enables the development of new ideas within different disciplines and subjects. At this junction, the authors acknowledge that seeking answers to this research question exposes the project management discipline to a lack of definitional consistencies. It is within this context that our study seeks to develop a more holistic understanding of what remains arguably multifaceted and complex concept within project management scholarship.

To attain this objective, we synthesize the diverse literature in a rigorous and systematic manner, but in marked contrast to similar studies by Turner et al. (2013a), our study however does not solely focus on ambidexterity mechanisms.

\section{Literature reviews as methods}

\section{Literature reviews as creative enquiries}

Fink (2010) defines a literature review as “...a systematic, explicit and reproducible method for identifying, evaluating and synthesizing the existing body of completed and recorded work produced by researchers, scholars, and practitioners" (p. 3). The review of literature according to Montuori (2005) represents a means of undertaking creative inquiry and dialogue within a community of scholars. The importance of the review of literature as the foundation of any attempt to understand existing theory is well recognized in the literature (Rowley and Slack, 2004; Montuori, 2005). It is thus a crucial initial 
step in any research endeavour encompassing the presentation, classification, comparison and evaluation in an organized manner of prior written information on the subject of interest (Bolderston, 2008). Schwarz et al. (2006) identifies the goals of a literature review as primarily (i) to provide a summary of previous research (ii) to undertake a critical examination of such previous research (iii) to provide an explanation of the results of such prior research and finally (iv) to provide clarifications on alternative perspectives of such research. In other words, for literature to be comprehensive, it has to be critical in that it must be able to consolidate knowledge on a subject matter in a manner which is evaluative.

\section{Systematic reviews}

In recent years, one of the popular approaches scholars have adopted to undertake a review of literature is the systematic approach (Xiao and Watson, 2017). The popularity of this review approach has extended to a range of disciplines including software engineering (Kitchenham et al., 2009), information systems (Rowe, 2014), organizational (Birkinshaw and Gupta, 2013), and general management studies (Crossan and Apaydin, 2010). More recently, systematic reviews have become popular in not only operations management (Thome et al., 2016; Maestrini et al., 2017), but also project management (Xue et al., 2010; Stingl and Geraldi, 2017; Lee et al., 2018). Systematic reviews of literature are defined by Rowe (2014), drawn from Kitchenham et al. (2009) as “...a form of secondary study that uses a well defined methodology to identify, analyse and interpret all available evidence related to a specific research question in a way that is unbiased and (to a degree) repeatable" (p. 246). Thus, the main ethos of the systematic review is that it emphasizes some form of precise and structured organization in its search, identification and selection of materials to be included in the review (Xiao and Watson, 2017).

\section{The study}

\section{The search}

The study was conducted in a manner consistent with systematic reviews of literature. One primary driver for this choice is that systematic literature reviews as highlighted by Thomé et al. (2016), emphasize rigour. In particular, unlike the traditional narrative approach to literature review, systematic reviews involves a process-driven collection and synthesis of material. Systematic reviews are also arguably transparent and reproducible (Tranfield, et al. 2003, p. 220). A much more detailed overview of the use of systematic literature reviews in the operations management context (and by implication, project management) is provided by Thomé et al. (2016). 
In line with specific guidelines on the use of systematic literature review (Tranfield et al., 2003; Thomé et al., 2016), the starting point of the literature search process was the selection of journals and databases to support the review. Two library and academic search databases (EBSCO and JSTOR) were chosen. The search in databases was also supported by specific searches in journals that appeared to have consistently published papers on the topic of interest, which is 'ambidexterity'. Here, we specifically identified three journals, Organization Science (OS), Journal of Management (JOM) and the Academy of Management Journals (AOM) - encompassing Academy of Management Review, Academy of Management Journal and the Academy of Management Perspectives. Other journals were also identified at a later stage with a particular focus on project management such as the International Journal of Project Management. We employed three keyword strings "ambidexterity", "ambidextrous" and "ambidex*” and varied their inclusion in the search functionality of the database with the alternate use of "AND" and "OR". The objective here was to ensure that the widest body of available literature was captured.

The first of the research articles found was published in 1991 while the last was published in 2016. Books, 'In Press' and unpublished articles were excluded from the selected sample. The initial sample was refined through a combination of steps that were based on guidance provided by Tranfield et al. (2003) and Thomé et al. (2016). The detailed guidance provided by Thomé et al. (2016) was deemed of particular relevance because their work is specific to operations management (within which project management as a discipline falls within). We slightly adjusted the various recommended processes to take into account the journal rankings and the number of times the article was cited in comparison with the year of publication. Each search and the number of used and analyzed publications is summarised in Table 1.

\section{INSERT Table 1 ABOUT HERE}

\section{Literature selection}

We developed six steps to guide our filtering of the initially identified publications. Although slightly adjusted in this study, these steps are consistent with earlier highlighted guidance on the conduct of systematic reviews articulated in Tranfield et al. (2003) and Thomé et al. (2016).

- Step 1: We sought to first identify publications to be incorporated within the study. This phase involved utilizing the keyword "ambidex"” as a key word during searches in the EBSCO and JSTOR database and other identified journals. 
- Step 2: Involved removing all identified duplication between databases and journal search results and then exporting the outcomes to a Microsoft Excel spreadsheet. During this step, we also ensured that all 'In Press', non-peer-reviewed and unpublished works were removed from the search results.

- Step 3: Involved reviewing the titles, abstracts and conclusions of the remaining articles in order to further refine the sample. This meant that articles which had been captured as part of the duplication rationalization, but which inevitably were not focused on ambidexterity were removed.

- Step 4: A check for completeness was undertaken with cited references in the remaining articles ascertained relevance. From this process, we identified 28 articles which had not been captured in our earlier search.

- Step 5: This step focused on quality checking. First, we reviewed the quality of the identified articles, discounting articles that were not ranked on the ABS Journal Quality List. In this step, the number of studies were filtered/reduced down to 45 . Those 45 articles are listed in Table 2 .

- Step 6: This final step involved a final check with focus on "ambidexterity" in the relevant context of projects. Most of the theoretical papers and sole literature reviews were dropped, but only after considering their list of references per Step 4. The taxonomical levels of ambidexterity were then constructed based on this final step. However, some of the papers which were discounted in Step 5 were considered in the study to identify indicators and attributes used to support how we conceptualized the study. In Table 3 and Table 4 shows the Analysis for the attributes and identifiers used to define "Dimensions" and "mechanisms" respectively. In sum, while the identified levels were derived from 36 reviewed articles, the final count of papers were in fact only 21 (as shown in Table 5), reflecting that in some instances, more than one level had been accounted for within a single publication.

INSERT Table 2 ABOUT HERE

INSERT Table 3 ABOUT HERE

INSERT Table 4 ABOUT HERE 
The review suggests considerable scholarly interest in ambidexterity commenced in approximately 2004, occurring again in 2010 and again in 2015, publications selected for use in the review were those published 2004 and 2016, during the peak of research which is shown in Table 1. From Step 6, nine papers were qualitative and twelve quantitative; five came from 2004-2007, four from 2008-2011, eleven from 2012-2015 and one from 2016-2017. In terms of industry, those papers covered a wide range of industry such as: Financial services/banking, Manufacturing and technology, Construction and engineering, Telecommunications, Research and Development (R\&D) projects and Management consulting.

\section{Analysis of the literature}

Thomé et al. (2016) suggests that in terms of systematic reviews of literature, “...there is no universal recipe for the analysis stage" (p.412). Thus, we drew upon Geraldi et al. (2011) for guidance on analysis. Our decision was based on this work being published within an operations and project context. Geraldi et al. (2011) had proposed five steps for analysing literature in systematic reviews. Thus, we adopted the following steps in our analysis.

The first step of our analysis focused primarily on extracting definitions and attributes that support conceptualization of levels of ambidexterity. In the second step, we undertook a grouping and meta-grouping of identified definitions and attributes. This facilitated the recognition of the different levels within project organisations where ambidexterity could be applied. We then inserted the year of publication into the resulting grouping of the literature. What this step suggested is that initial literature on ambidexterity appeared predominantly focused on its individual level (see for example Swart et al. 2016), although some literatures such as Jansen et al. (2005) did explore its operational level application. As indicated, the second step of analysis involved grouping and meta-grouping which led to the recognition of the different levels within project organisations where ambidexterity could be applied. The analysis which was undertaken at this step used articles with empirical background as identified in step 6 of the systematic review of the literature (i.e. it used the 21 articles of step 6 of the systematic review) - this is mostly presented in Table 3,4 and 5. The analysis carried out in the second step generated two further attributes of ambidexterity, those are identified as (i) the dimensions and the mechanisms of ambidexterity.

\section{INSERT Table 5 ABOUT HERE}


The third step of the analysis focused on re-validating the notion of levels by revisiting the most relevant articles, and this triggered the fourth step of the analysis. The fourth step focused on revalidating dimensions and mechanisms of ambidexterity using articles from step 5 of the systematic review (i.e. using the larger pool of the 45 articles as listed in Table 3). The intention behind this exercise was to gather a greater pool of the identified literature to explore all possible mechanisms of ambidexterity and categorize them for ease of use and identification. The fifth (and final step) involved analysing dimensions of ambidexterity against levels of ambidexterity as represented in Table 6 . In other words, we have looked into more details of what dimensions can be found in each of the levels identified. This final step serves as means of understanding what dimensions of ambidexterity are expected at each level of the organization. An additional and similar type of analysis was also undertaken against dimensions of ambidexterity and its mechanisms. This is presented in Table 7.

\section{INSERT Table 6 ABOUT HERE}

\section{INSERT Table 7 ABOUT HERE}

In light of the above discussion, we have summarized the notion of levels, dimensions and mechanisms in Figure 1 for ease of reference.

\section{INSERT Figure 1 ABOUT HERE}

Finally, the literature suggests a number of the influencers, which could have an effect on the levels, dimensions and mechanisms of ambidexterity. These influencers consist of external environmental factors (Lavie et al. 2010), and other parameters such as resource availability, firm size (Choi and Phan, 2014) and dynamic capabilities (Rothaermel and Alexandre 2009).

\section{The findings}

\section{Levels, dimensions and mechanisms of ambidexterity}

Four levels of ambidexterity which we termed 'strategic', 'project', 'operations' and 'individual' were identified in our study, resonating with ongoing multi-level (Costa et al., 2013) and diversity (Harrison and Klein, 2007) perspectives within organisation studies. We draw upon Rousseau (1985) to define levels as 'the hierarchical relationship and attributes of the constituent elements of an organisation' (p. 3 
and 4). According to Gibson and Birkinshaw (2004), managing ambidexterity requires connections to be made between various levels of ambidexterity in order to facilitate their alignment. We are interested in these levels as Chandrasekaran et al. (2012) suggests that tensions occur at multiple levels of an organization and that an organisation's inability to manage the tensions associated with ambidexterity at both its strategic and project levels can create substantial difficulties.

\section{Levels of ambidexterity}

The literature suggests that it is at the strategic level that exploration and exploitation decisions are made within an organization (Chandrasekaran et al., 2012). It is also at this level that decisions are made on how the organization will be designed and structured in order to support exploitative or exploratory opportunities are made (Bednarek et al., 2016). To resolve the tensions associated with ambidexterity, senior managers will usually draw upon their knowledge about the external market and their understanding of the organisations competencies and capabilities (Wei et al., 2014).

While the literature suggests that decisions relating to managing opportunities emanating from exploitative or exploratory opportunities takes place at the strategic level of organisations, these opportunities can only be made ready for use at the project level supported by specific project architectures or project management processes. In fact, it is at the project level that organisations align and adapt to changes in the market associated with exploitative or exploratory.

In terms of specific project architectures to support ambidexterity, a number of different architectures can be adopted. For example, the organisation can choose to adopt dual architectures to manage its exploitative and exploratory opportunities. Such approach implies physically separating between exploitative and exploratory-related activities. Organisation can also choose to adopt dual methods of project delivery, with loosely 'coupled' project mechanism (in effect, loose abidance to specifications and client requirements) focusing on exploitation while tightly coupled delivery mechanism which emphasis rigid controls and tight abidance to client needs being utilized to deliver exploitative focused opportunities. The challenge of project team architecture specificity under ambidexterity is that project environments are particularly dynamic and complex while in a number of cases, project teams are structured in a less than agile manner (Mishra and Sinha, 2016), that may be unable to support the demand for almost immediate agility. The literature suggests that how projects are structured may actually influence how individual projects behave. Certain project architectures appear more suitable for projects that are routine and focus on efficiencies, while some other architectures, 
usually those that tend to be more organic, are more suitable to projects, particularly those with high pace and complexity that emphasize adaptability and flexibility.

On the question of project management processes, concerned about potential limitations of control-dominant philosophies, scholars such as Leybourne and Sainter (2012) have emphasised an ongoing shift in project and team outlook to an emphasis on improvisation. However, we posit that such approaches face a number of boundary integration challenges as the operational level provides the necessary platform for resources common to the strategic and project level to be shared. It is important to highlight that a focus on improving ambidexterity at a strategic level with no or slight consideration for the operational aspects reduces prospects of the organization developing, deploying, and leveraging flexibility.

As the lowest level of ambidexterity is the 'individual' level. Mom et al. $(2007,2009)$ focus on how individuals within an organization can actually organize, mobilise and manage exploitation and exploration. Jørgensen and Becker (2017) suggests that maintaining either a relationship-centric or expert-centric team design can promote ambidextrous capacities in teams. The same will arguably apply to project teams where behavioural response to the daily tensions associated with the need to balance opportunity exploitation against its exploration by individual project managers (Turner at al., 2013b) and project team members (Liu and Leitner, 2012) is expected to contribute to project success. The literature also suggests that the set of characteristics of individual project managers is a contributing factor to the success of projects (Chipulu et al., 2013; Petro \& Gardiner, 2015). Similarly, project stakeholder theory suggests that individual stakeholders contribute significantly to project success (Ojiako et al., 2015).

\section{Dimensions of ambidexterity}

We identified four ambidexterity dimensions which included 'knowledge', 'technology', 'process' and 'behaviour'. Here, by 'dimensions', we are referring to specific organizational features which could create paradox(es) amongst themselves and which could lead to a contagious effect on the host organization. It is contended in this research that a resolution of such paradox(es), whether this resolution takes place within one or a group of dimensions, should see enhanced performance and business sustainability throughout.

A frequently discussed theme in ambidexterity-related research is the paradox in managing the contradiction between a short-term focus on exploiting repetitive and well-defined knowledge and the need for organisations to balance this against the need to expand the organisation's knowledge of new ideas (Raisch et al., 2009). Since both elements are critical for sustainable competitive advantage, firms 
need to explicitly manage both exploration and exploitation (Gupta et al., 2006). Thus, organisations that are ambidextrous are those that show a capability to develop and at the same time, seek (and also) manage knowledge which may be unfamiliar (exploration).

The literature, for example Chandrasekaran et al. (2012) and Voss and Voss (2013), suggests that technology, that is the practical application of knowledge of a scientific nature, can serve as an aid to manage ambidexterity and exploit its opportunities through its ability to enable firms to fully exploit their resource base, develop novel products and enter new markets. For these reasons, organisations with a lower level of technological capability tend to focus more on exploiting opportunities while organisations with higher level of technology competency tend to focus more on exploring opportunities (Zang and $\mathrm{Li}$, 2017).

Process refers to a series of carefully crafted multi-level routines and actions that the organization will engage with in order to achieve a desired balance between exploitation and exploration (Zimmermann et al., 2015). The process dimension is particularly interested in resolving trade-offs arising from for example process variations (Matthews et al., 2015) and trade-off between operational efficiencies and strategic flexibilities (Kortmann et al., 2014). The literature suggests that organisations have the ability to build "....a set of processes or systems that enable and encourage individuals to make their own judgments about how to divide their time between conflicting demands for alignment and adaptability" (Gibson and Birkinshaw, 2004, 211). Zimmermann et al. (2015) found for example that although members of the top management team in an organisation at a specific point will (i) highlight a need for the organisation to adopt ambidexterity, (ii) follow this up by designing organizational structures which will support such ambidexterity, in reality, organisations also do depend on this process being complemented by an emergent form of ambidexterity which is driven from the bottom by project-level managers responding to changes in competitive realities which sometimes the top management team is unaware of.

A behavioural perspective of ambidexterity also exists in the literature (see Patel et al., 2012). Here, the emphasis is on resolving the tension between 'hard elements' of behaviour such as discipline and 'soft elements' such as support and trust. The literature suggests that in order to effectively manage prevalent tensions associated with ambidexterity, an organization need to demonstrate behavioural capabilities that suggests an ability to simultaneously exploit and explore (Jansen et al., 2009).Thus, the behavioural perspective focuses on the way organisations (and its individual managers) responds to ambidextrous stimuli. The attributes of such behaviour are generally according to Ghoshal and Bartlet (1994) manifested at the level of the operational unit. 


\section{Mechanisms of ambidexterity}

We also identified mechanisms of ambidexterity. By mechanism, we suggest by referring to the works of both Jansen et al. (2009) and Turner et al. (2013a), the specific established means by which organization's manage the contradictions and tensions associated with ambidexterity. Against this attribute, we identified from the analysis, four sets of mechanisms for resolving the tensions we had identified in this attribute: (i) structural mechanisms, (ii) learning mechanisms, (iii) selection/allocation mechanisms - which encompassed for example the allocation of resources to meet market demands and the balancing of resources to equalize between codified knowledge and new knowledge (Matthews et al. 2015) - and (iv) communication mechanisms - which dealt with for example formalization and communication of rules (Mom et al. 2009).

We observed that structural mechanisms were the most mentioned in the literature. In terms of the learning mechanisms for example, at the individual level, ambidextrous individuals have the ability to learn from previous events to enhance application for future circumstances. Also, they have the ability to learn as they go-about adapting to evolving circumstances (Aubry and Lievre, 2010). On the other hand, in terms of communication mechanisms, the literature alludes to knowledge sharing and communication being one of the key attributes to achieving ambidexterity (Jansen et al., 2005; Mom et al., 2007). An improved level of communication allows integration at all levels of the organization. Integration at the knowledge workers' level can be achieved by the organisation focusing on creating an environment conducive to "trust and reciprocity" (Turner et al., 2015).

We note that the mechanisms defined here may resemble in one way or another Turner et al's (2013a) mechanisms, where he used the organization's Intellectual Capital for this purpose. Our definition and the detailed analysis we provided for mechanisms however delves into the 'micro-level' for those compared to Turner et al's (2013a) general definition and approach. We also believe that our definition, with its 'micro- level' approach, provides a platform for their 'applicability' - which is an area of a great concern per Turner et al (2013a).

\section{Discussion}

The concept of ambidexterity is increasingly important within organisations. This interest has been supported by extensive research mainly in general management and organisation studies literature. However, although strategic initiatives within organisations are in most cases realised through the structure provided by projects, there is a paucity of research on ambidexterity set explicitly within the 
context of project management. This is however set to change following growing interest in the topic among project and engineering management scholars. This suggests an increasing realisation among project management practitioners and scholars that projects represent perhaps the best means of contextualising ambidexterity.

In view of the research question presented at the start of the paper, "What is a project management focused definition of ambidexterity taking note of the evolution of organizational ambidexterity literature?", ambidexterity is the ability of the organization to employ a range of techniques to resolve paradoxical challenges within all levels of the organization (separate and interwoven) to overcome external competition and dynamics, taking into account internal limiting factors, such as size, resource availability, and absorptive capacity of the organization.

The implementation of these as a strategy is realised through projects requires looking at governance of projects in a new light, bearing in mind ambidexterity, whose definition we here expand to:

Ambidexterity is the ability of the organization to employ structural, learning, selection, and communication techniques to resolve paradoxical challenges within intellectual, behavioural, technological, and processual dimensions in the various levels of the organization-these levels (strategic, projects, operations, and individual) can be separate or interwoven-to overcome situations of external dynamicity and competitive environments, considering internal limiting factors such as size, resources availability, and absorptive capacity of the organization.

At this point, we reiterate that the objective of our study is to contribute to scholarship by advancing an understanding of the ambidexterity concept that is set within the context of project management. As such, the intention of this paper holds as far as it provides a more specific and by implication, informative definition for ambidexterity that is more readily applicable, beneficial and meaningful to project management scholars and practitioners. It is not the intention of this study that this project-contextualised definition for ambidexterity replaces well recognised definitions of ambidexterity that have so far been articulated in the literature.

The study contributes to project management theory and practice in three ways which are distinct. The first contribution of the paper is that it sets the scene for vibrant dialogue and debate in relation to project-contextualised ambidexterity. In doing this, while taking into consideration the evolution of project-contextualised ambidexterity literature such as that of Turner et al. (2013a, 2013b, 2014, 2015, 
2016) and Bednarek et al. (2016), this is the first study that explores the potential for an expanded project management focused definition of ambidexterity.

Second, our findings suggests that ambidexterity can be viewed from different levels, dimensions and mechanisms. We identified four such levels consisting of the strategic level, the project level, the operational level and finally, the 'individual' level. In terms of dimensions, we identified four consisting of 'knowledge', 'technology', 'process' and 'behaviour'. We also identified four sets of mechanisms of ambidexterity, namely structural mechanisms, learning mechanisms, selection/allocation mechanisms and communication mechanisms. Each of the different levels, dimensions and mechanisms of ambidexterity were associated with attributes and/or identifiers. Analysis appears to suggest not only that each level, dimension and mechanism of ambidexterity are able to support both exploitation and exploration, but also that these attributes are interconnected. As we examine each of these different levels, dimensions and mechanisms, we suggests that they represent specific aspects of project-based organising. The consideration of levels, including the project level, is important to understand the ambidextrous nature. It is at this level that organisations can align and adapt to approach exploitative or exploratory opportunities. In developing project management structures, it is important to recognise the different requirements of exploitative and exploratory opportunities. Some structures and projectmanagement philosophies will be more suited to the different demands of each. Similarly, when exploring project management processes, it will appear that ambidexterity requires a strong connection between the strategic and operational level which seems to be often lacking in practice. These findings are also indicative of the complexity of the relationships between the different levels, dimensions and mechanisms of ambidexterity.

Third, our study findings offer project management scholars and practitioners a point of reference for further research into the different levels, dimensions and mechanisms of project-contextualised ambidexterity. In effect, our findings serves as a foundation for building much more understanding of the levels, dimensions and mechanisms of project-contextualised ambidexterity in other organisational forms which may be emerging. These may include autonomous -managed networks. Our findings would arguably equally apply to other disciplines which are aligned to project management. One such discipline could be programme management.

Bartolucci et al. (2010) had suggested that a concern with systematic reviews often relates to questions as to whether the eligibility criteria of the identified literature reviewed were consistent and well established. Noting this, further studies may choose to undertake exploratory meta-analysis in order to further ensure consistency in literature selection. However, despite this limitation, engaging in the 
literature using a systematic review allowed for a detailed understanding of the broad range of perspectives held by scholars and practitioners on the different levels, dimensions and mechanisms of a project-contextualised form of ambidexterity. Thus, future studies, as well as meta-analysis, may also choose to undertake critically scrutinise the different levels, dimensions and mechanisms of any such project-contextualised form of ambidexterity. There are two ways this can be done. Firstly, it may be through quantitative research which will focus on understanding the relationship between these the different levels, dimensions and mechanisms. Secondly, it may be done through qualitative studies, in this instance, through case study research. The obvious benefit of case study research will be that through intimate engagement with practitioners, we will be able to develop a project-contextualised form of ambidexterity that is relevant to project management practice. This will overcome our earlier observation that ambidexterity is seen as being of little or no relevance to practice since it remains largely theoretically constructed. Future studies can look at different practices which could be customized within the organization to serve achieving ambidexterity, one of such practices could be those of the project portfolio management. Project portfolio management practices in this case can be looked at closely along with those mechanisms of ambidexterity as generated in this study to identify similarities for ease of application and practicality in use.

Finally, there is ample opportunity in terms of future studies focused on testing not only the validity of our conclusions - which proposed that that a project-focused notion of organisational ambidexterity involved different levels, dimensions and mechanisms - but also testing how the interface between these different levels, dimensions and mechanisms do specifically impact upon a projectfocused notion of organisational ambidexterity. What we have been able to demonstrate in this paper is that a project-focused notion of organisational ambidexterity involves different levels, dimensions and mechanisms and that this taxonomy is useful in terms of both understanding and analysing organisational ambidexterity. Each of the propositions presents opportunities for distinct further studies that will be enhanced through empirical works. Noting that while prior empirical studies on ambidexterity exist, the majority have focused on the organisational level (Kassotaki et al., 2018; Zimmermann et al., 2018), future studies emanating from our study can proceed in a number of directions. For example, cognizant of recent studies by Kassotaki et al. (2018), future research could seek to examine not only (i) how ambidexterity is manifested across theses different levels, dimensions and mechanisms of ambidexterity, but also (ii) how ambidexterity is managed across different organisational levels, cognizant of its varying dimensions and mechanisms. Such studies, for example when undertaken from the lens of project readiness (see Jones et al., 2005; Ahmadi et al., 2015; Ram and Corkindale, 2015; Shokri et al., 2016) 
will serve as a means of gaining more meaningful insight into the interplay between the different levels, dimensions and mechanisms of a project-focused notion of organisational ambidexterity. Another direction for future research is to explore the proactive role that project managers play during the initiation of ambidextrous strategies beyond the borders of the projects they manage. For example, while a substantial amount of ambidexterity research appears to point to senior executives serving as the central driving force and key decision originators in the implementation of firm-based solutions for ambidexterity (Tushman and O'Reilly, 1996; Tushman and Euchner, 2015; Birkinshaw and Gibson, 2004; Gibson and Birkinshaw, 2004; Lubatkin et al., 2006; Jansen et al., 2008; Raisch et al., 2009; Simsek, 2009; Mihalache et al., 2014; Jurksiene and Pundziene, 2016), the reality could be otherwise. Zimmermann et al. (2018) for example suggests that 'frontline managers' (known for their autarchic strategic behaviour - see Burgelman, 1983) actually play an active role in shaping the processes and systems organisations require to balance the countenance of ambidexterity's two contradictory analytical constructs. Drawing from Thorpe and Mead (2001), "Frontline supervisors typically include the project managers" (p. 409).

\section{Conclusion}

We have established both the importance of the concept of ambidexterity and the lack of its research set explicitly within the context of project management. In the light of this, we have widened the definition of ambidexterity to encompass a project-focused understanding of the concept. We have described a taxonomical analysis of contemporary organisational ambidexterity literature. Our findings suggests that ambidexterity can be viewed from different levels, dimensions and mechanisms, and we specify each of these. Our analysis suggests that each level, dimension and mechanism are able to support both exploitation and exploration, that they represent specific aspects of project-based organising, and that these attributes are interconnected in complex ways. In doing this we also help to set the scene for dialogue around project-contextualised ambidexterity, and provide a point of reference for further research. We have further pointed to further work to strengthen these first steps, suggesting studies relating to specific propositions, exploratory meta-analyses, further quantitative study of the different levels, dimensions and mechanisms and their relationships, contextualised case studies, and on the practical proactive role that project managers play. This paper therefore forms an important step in understanding the concept of ambidexterity within the project context upon which academics and practitioners can build upon. 


\section{References}

Adler, P., Goldoftas, B., and Levine, D. I. (1999). "Flexibility versus efficiency: A case study of model changeovers in the Toyota production system.” Organization Science, 10, 43-68.

Ahmadi, S. Papageorgiou, E. Yen, C., and Marin, R. (2015). "Managing readiness-relevant activities for the organizational dimension of ERP implementation." Computers in Industry, 68, 89 - 104.

Andriopoulos, C., and Lewis, M. (2009). "Exploitation-exploration tensions and organizational ambidexterity: Managing paradoxes of innovation.” Organization Science, 20(4), 696-717.

Ansari, R., Shakeri, E. and Raddadi, A. (2014). "Framework for aligning project management with organizational strategies. ASCE Journal of Management in Engineering, 31(4), p.04014050.

Aubry, M., and Lièvre, P. (2010). “Ambidexterity as a competence of project leaders: A case study from two polar expeditions.' Project Management Journal, 41(3), 32-44.

Bakker, R., DeFillippi, R., Schwab, A., and Sydow, J. (2016). "Temporary organizing: Promises, processes, problems.” Organization Studies, 37(12), 1703-1719.

Bednarek, R., Burke, G., Jarzabkowski, P., and Smets, M. (2016). "Dynamic client portfolios as sources of ambidexterity: Exploration and exploitation within and across client relationships.” Long Range Planning, 49, 324-341.

Benner, M., and Tushman, M. (2003). "Exploitation, exploration, and process management: The productivity dilemma revisited." Academy of Management Review, 28, 238-256.

Birkinshaw, J. and Gibson, C. (2004). "Building ambidexterity into an organization". Sloan Management Review, 45, 47-55.

Birkinshaw, J., and Gupta, K. (2013). "Clarifying the distinctive contribution of ambidexterity to the field of organization studies.” Academy of Management Perspectives, 27(4), 287-298.

Bolderston, A. (2008). "Writing an Effective Literature Review. "Journal of Medical Imaging and Radiation Sciences. 39 (2), 86-92.

Burgelman, R. (1983). "A model of the interaction of strategic behavior, corporate context, and the concept of strategy". Academy of Management Review, 8 (1), 61-70.

Burgelman, R. (2002). "Strategy as vector and the inertia of coevolutionary lock-in." Administrative Science Quarterly, 47, 325-357.

Cao, R., Kavadias, S., and Gaimon, C. (2009). "Revenue driven resource allocation: Funding authority, incentives, and new product development portfolio management.” Management Science, 55(9), $1556-1569$. 
Cerchione, R., Centobelli, P., Esposito, E., and Raffa, M. (2016). "What is the Engineering Management? Exploring the Emerging Knowledge and Skills for Engineers." Advanced Science Letters, 22(56), 1535-1537.

Chandrasekaran, A., Linderman, K., and Schroeder, R. (2012). "Antecedents to ambidexterity competency in high technology organizations." Journal of Operations Management, 30, 134 151.

Chen, Q. and Liu, Z. (2018). "How Does Openness to Innovation Drive Organizational Ambidexterity? The Mediating Role of Organizational Learning Goal Orientation.” IEEE Transactions on Engineering Management, (99), 1-14.

Chipulu, M., Neoh, J., Ojiako, U., and Williams, T. (2013). “A multidimensional analysis of project manager competences." IEEE Transactions on Engineering Management, 60 (7), 506-517

Chiu, Y. (2014). "Balancing exploration and exploitation in supply chain portfolios." IEEE Transactions on Engineering Management, 61(1), 18-27.

Cao, Q., Gedajlovic, E. and Zhang, H., (2009). "Unpacking organizational ambidexterity: Dimensions, contingencies, and synergistic effects.” Organization Science, 20(4), pp.781-796.

Choi, Y., and Phan, P. (2014). "Exploration, exploitation, and growth through new product development: The moderating effects of firm age and environmental adversity." IEEE Transactions on Engineering Management, 61(3), 428-437.

Choi, S., Cho, I., Han, S., Kwak, Y., and Chih, Y. (2018a). "Dynamic Capabilities of Project-Based Organization in Global Operations.” ASCE Journal of Management in Engineering, 34(5), 04018027.

Choi, B., Ravichandran, T., Colarelli, and O'Connor, G. (2018b). "Organizational Conservatism, Strategic Human Resource Management, and Breakthrough Innovation.” IEEE Transactions on Engineering Management, In Press

Costa, P., Graça, A., Marques-Quinteiro, P., Santos, C., Caetano, A., and Passos, A. (2013). "Multilevel research in the field of organizational behaviour: An empirical look at 10 years of theory and research.” Sage Open, 3(3), 1-17.

Crossan, M., and Apaydin, M. (2010). “A multi-dimensional framework of organizational innovation: A systematic review of the literature." Journal of Management Studies, 47(6), 1154-1191.

Danneels, E. (2002). "The dynamics of product innovation and firm competences." Strategic Management Journal, 23(12), 1095-1121. 
Du, W., Pan, S. and Zuo, M. (2013). "How to balance sustainability and profitability in technology organizations: An ambidextrous perspective.” IEEE Transactions on Engineering Management, 60(2), pp.366-385.

Eriksson, P. (2013). "Exploration and exploitation in project-based organizations: Development and diffusion of knowledge at different organizational levels in construction companies." International Journal of Project Management, 31(3), 333-341.

Evans, W., and Bredin, C. (1987). "Transition from engineering to management." ASCE Journal of Management in Engineering, 3(3), 220-231.

Fink, A. (2010), Conducting Research Literature Reviews: From the Internet to Paper, 3rd ed. Sage, Thousand Oaks.

Geraldi, J., and Söderlund, J. (2017). "Project studies: What it is, where it is going." International Journal of Project Management, 36, 55-70.

Geraldi, J., Maylor, H., and Williams, T. (2011). "Now, let's make it really complex (complicated): A systematic review of the complexities of projects." International Journal of Operations \& Production Management, 31(9), 966-990.

Ghoshal, S., and Bartlett, C. (1994). "Linking organizational context and managerial action: The dimensions of quality of management.” Strategic Management Journal, 15, 91-112.

Gibson, C., and Birkinshaw, J. (2004). "The antecedents, consequences, and mediating role of organizational ambidexterity.” Academy of Management Journal, 47, 209-226.

Gupta, A., Smith, K., and Shalley, C. (2006). "The interplay between exploration and exploitation." Academy of Management Journal, 49, 693-706.

Harrison, D., and Klein, K. (2007). "What's the difference? Diversity constructs as separation, variety, or disparity in organizations." Academy of Management Review, 32(4), 1199-1228

He, Z., and Wong, P. (2004). "Exploration vs. exploitation: an empirical test of the ambidexterity hypothesis.” Organization Science, 15, 481-494.

Hitt, M., Beamish, P., Jackson, S., and J. Mathieu, J. (2007). "Building Theory and Empirical Bridges across Levels: Multilevel Research in Management.” Academy of Management Journal. 50, 1385-1399.

Hoang, H., and Rothaermel, F. (2010). "Leveraging internal and external experience: exploration, exploitation, and R\&D project performance.” Strategic Management Journal, 31(7), 734-758.

Im, G., and Rai, A. (2008). "Knowledge sharing ambidexterity in long-term interorganizational relationships.” Management Science, 54, 1281-1296. 
Jansen, J., Van den Bosch, F., and Volberda, H. (2005). "Exploratory innovation, exploitative innovation, and ambidexterity: the impact of environmental and organizational antecedents." Schmalenbach Business Review, 57, 351-363.

Jansen, J., George, G., Van den Bosch, F., and Volberda, H. (2008). "Senior team attributes and organizational ambidexterity: The moderating role of transformational leadership." Journal of Management Studies, 45(5), 982-1007.

Jansen, J., Tempelaar, M., Van den Bosch, F., and Volberda, H. (2009). "Structural differentiation and ambidexterity: The mediating role of integration mechanisms.” Organization Science, 20(4), 797 811.

Jansen, J., Simsek, Z., and Cao, Q. (2012). “Ambidexterity and performance in multiunit contexts: Crosslevel moderating effects of structural and resource attributes." Strategic Management Journal, $33,1286-1303$.

Jones, R., Jimmieson, N., and Griffiths, A. (2005). "The impact of organizational culture and reshaping capabilities on change implementation success: The mediating role of readiness for change." Journal of Management Studies, 42(2), 361-386.

Jørgensen, F., and Becker, K. (2017). "The role of HRM in facilitating team ambidexterity.” Human Resource Management Journal, 27(2), 264-280.

Jurksiene, L., and Pundziene, A. (2016). "The relationship between dynamic capabilities and firm competitive advantage: The mediating role of organizational ambidexterity." European Business Review, 28(4), 431-448.

Kassotaki, O., Paroutis, S., and Morrell, K. (2018). "Ambidexterity penetration across multiple organizational levels in an aerospace and defense organization." Long Range Planning, doi.org/10.1016/j.lrp.2018.06.002, 1-20.

Kitchenham, B., Brereton, O., Budgen, D., Turner, M., Bailey, J., and Linkman, S. (2009). "Systematic literature reviews in software engineering - a systematic literature review." Information and Software Technology, 51(1), 7-15.

Kline, R. (1995). “Construing 'Technology' as 'Applied Science': Public Rhetoric of Scientists and Engineers in the United States, 1880-1945." Isis, 86, 194-221

Kortmann, S., Gelhard, C., Zimmermann, C., and Piller, F. (2014). "Linking strategic flexibility and operational efficiency: The mediating role of ambidextrous operational capabilities." Journal of Operations Management, 32, 475-490. 
Kotnour, T., and Farr, J. (2005). "Engineering management: past, present, and future." Engineering Management Journal, 17(1), 5-26.

Kristal, M., Huang, X., and Roth, A. (2010). "The effect of an ambidextrous supply chain strategy on combinative competitive capabilities and business performance." Journal of Operations Management, 28, 415-429.

Kuprenas, J.A., Madjidi, F. and Smith, B. (1999). "Implementation of project management in public engineering organization.” ASCE Journal of Management in Engineering, 15(3), 69-77.

Lavie, D., Stettner, U., and Tushman, M. (2010). "Exploration and exploitation within and across organizations." Academy of Management Annals, 4(1), 109-155.

Lee, G., Delone, W., and Espinosa, J. (2006). “Ambidextrous coping strategies in globally distributed software development projects." Communications of the ACM, 49, 35-40.

Lee, C., Wu, H. and Liu, C. (2013). "Contextual determinants of ambidextrous learning: Evidence from industrial firms in four industrialized countries." IEEE Transactions on Engineering Management, 60(3), 529-540.

Lee, C., Chong, H., Liao, P., and Wang, X. (2018). "Critical Review of Social Network Analysis Applications in Complex Project Management.” ASCE Journal of Management in Engineering, 34(2), p.04017061.

Lenfle, S., and Loch, C. (2010). "Lost roots: how project management came to emphasize control over flexibility and novelty." California Management Review, 53(1), 32-55.

Leybourne, S., and Sainter, P. (2012). “Advancing Project Management: Authenticating the Shift from Process to "Nuanced" Project-Based Management in the Ambidextrous Organization." Project Management Journal, 43(6), 5-15.

Levinthal, D. and March, J. (1993). “The myopia of learning.” Strategic Management Journal, 14(S2), pp.95-112.

Ligthart, R., Oerlemans, L. and Noorderhaven, N. (2016). "In the shadows of time: A case study of flexibility behaviors in an interorganizational project." Organization Studies, 37(12), 1721-1743.

Lim, B., Ling, F., Ibbs, C., Raphael, B. and Ofori, G. (2011). "Mathematical models for predicting organizational flexibility of construction firms in Singapore." ASCE Journal of Construction Engineering and Management, 138(3), 361-375.

Lin, H., and McDonough, E. (2011). "Investigating the role of leadership and organizational culture in fostering innovation ambidexterity." IEEE Transactions on Engineering Management, 58 (3), 497-509. 
Liu, L., and Leitner, D. (2012). "Simultaneous pursuit of innovation and efficiency in complex engineering projects - A study of the antecedents and impacts of ambidexterity in project teams." Project Management Journal, 43(6), 97-110.

Liu, L., Wang, X., and Sheng, Z. (2012). “Achieving ambidexterity in large, complex engineering projects: a case study of the Sutong Bridge project." Construction Management and Economics, 30(5), 399-409.

Lubatkin, M., Simsek, Z., Ling, Y., and Veiga, J. (2006). “Ambidexterity and performance in small- to medium-sized firms: the pivotal role of top management team behavioural integration." Journal of Management, 32, 646-672.

Lynn, L. (2002). "Engineers and engineering in the US and Japan: A critical review of the literature and suggestions for a new research agenda." IEEE Transactions on Engineering Management, 49(2),95-106.

Maestrini, V., Luzzini, D., Maccarrone, P., and Caniato, F. (2017). "Supply chain performance measurement systems: A systematic review and research agenda." International Journal of Production Economics, 183, 299-315.

Markides, C. (2013). "Business model innovation: What can the ambidexterity literature teach us?" Academy of Management Perspectives, 27(4), 313-323.

Marshall, A., Ojiako, U., Wang, V., Lin, F., and Chipulu, M. (2018). "Forecasting Unknown/Unknowns by Boosting the Risk Radar within the Risk Intelligent Organisation." International Journal of Forecasting, In Press.

Matthews, R., Tan, K., and Marzec, P. (2015). "Organizational ambidexterity within process improvement." Journal of Manufacturing Technology Management, 26(4), 458-476.

McGrath R. (2001). "Exploratory learning, innovative capacity, and managerial oversight." Academy of Management Journal, 44(1), 118-131.

Mihalache, O., Jansen, J., Van den Bosch, F. and Volberda, H. (2014). “Top management team shared leadership and organizational ambidexterity: A moderated mediation framework." Strategic Entrepreneurship Journal, 8(2), 128-148.

Mishra, A., and Sinha, K. (2016). "Work design and integration glitches in globally distributed technology projects.” Production and Operations Management, 25(2), 347-369.

Mom, T., Van Den Bosch, F., and Volberda, H. (2007). "Investigating managers' exploration and exploitation activities: The influence of top-down, bottom-up, and horizontal knowledge inflows.” Journal of Management Studies, 44(6), 910-931. 
Mom, T., Van Den Bosch, F., and Volberda, H. (2009). "Understanding variation in managers' ambidexterity: Investigating direct and interaction effects of formal structural and personal coordination mechanisms." Organization Science, 20(4), 812-828.

Montuori, A. (2005). "Literature review as creative inquiry: Reframing scholarship as a creative process." Journal of Transformative Education, 3(4), 374-393.

Morris, P., Crawford, L., Hodgson, D., Shepherd, M., and Thomas, J. (2006). "Exploring the role of formal bodies of knowledge in defining a profession-The case of project management." International Journal of Project Management, 24(8), 710-721.

Nemanich, L., and Vera, D. (2009). "Transformational leadership and ambidexterity in the context of an acquisition." Leadership Quarterly, 20, 19-33.

O'Connor, G., and DeMartino, R. (2006). “Organizing for radical innovation: an exploratory study of the structural aspects of RI management systems in large established firms." Journal of Product Innovation Management, 23, 475-97.

O'Reilly, C., and Tushman, M. (2008). "Ambidexterity as a dynamic capability: resolving the innovator's dilemma." Research in Organizational Behaviour, 28, 185-206.

O'Reilly, C., and Tushman, M. (2011). “Organizational ambidexterity in action: how managers explore and exploit." California Management Review, 53, 5-22.

O'Reilly, C., and Tushman, M. (2013). "Organizational ambidexterity: Past, present, and future." Academy of Management Perspectives, 27(4), 324-338.

Ojiako, U., Chipulu, M., Marshall, A., Ashleigh, M., Maguire, S., Williams, T., and Obokoh, L. (2015). "Heterogeneity and perception congruence of project outcomes." Production Planning \& Control, 26(11), 858-873.

Omurtag, Y. (2009). "What is engineering management? A new look at an old question.” Engineering Management Journal, 21(4), 3-6.

Patel, P.C., Terjesen, S., and Li, D. (2012). "Enhancing effects of manufacturing flexibility through operational absorptive capacity and operational ambidexterity." Journal of Operations Management, 30(3), 201-220.

Pellegrinelli, S., Murray-Webster, R., and Turner, N. (2015). "Facilitating organizational ambidexterity through the complementary use of projects and programs." International Journal of Project Management, 33(1), 153-164. 
Petro, Y., \& Gardiner, P. (2015). "An investigation of the influence of organizational design on project portfolio success, effectiveness and business efficiency for project-based organizations." International Journal of Project Management, 33, 1717-1729.

Petro, Y. (2017). Ambidexterity Through Project Portfolio Management: Resolving Paradoxes in Organizations. British University in Dubai, Unpublished PhD Thesis.

Picon, A. (2004). "Engineers and engineering history: Problems and perspectives." History and technology, 20(4), 421-436.

Prado, P., and Sapsed, J. (2016). "The anthropophagic organization: How innovations transcend the temporary in a project-based organization.” Organization Studies, 37(12), 1793-1818.

Raisch, S., and Birkinshaw, J. (2008). “Organizational ambidexterity: Antecedents, outcomes, and moderators." Journal of Management, 34(3), 375-409.

Raisch, S., Birkinshaw, J., Probst, G., and Tushman, M. (2009). "Organizational ambidexterity: balancing exploitation and exploration for sustained performance. Organization Science, 20, $685-695$.

Ram, J., and Corkindale, D. (2015). "Examining the role of organizational readiness in ERP Project Delivery”. Journal of Computer Information Systems, 2(1), 29-40.

Rashman, L., Withers, E., and Hartley, J. (2009). "Organizational learning and knowledge in public service organizations: A systematic review of the literature." International Journal of Management Reviews, 11(4), 463-494.

Rosenkopf, L., and Nerkar, A. (2001). "Beyond local search: Boundary-spanning, exploration, and impact in the optical disk industry." Strategic Management Journal, 22(4), 287-306.

Rothaermel, F., and Alexandre, M. (2009). "Ambidexterity in technology sourcing: The moderating role of absorptive capacity." Organization Science, 20(4), 759-780.

Rousseau, D. (1985). "Issues of level in organizational research: Multilevel and cross-level perspectives." Research in Organizational Behaviour, 7, 1-37.

Rowe, F. (2014). "What literature review is not: diversity, boundaries and recommendations." European Journal of Information Systems, 23(3), 241-255.

Rowley, J., and Slack, F. (2004) Conducting a literature review. ” Management Research News, 27(6), 31-39.

Rowley, T., Behrens, D., and Krackhardt, D. (2000). "Redundant governance structures: An analysis of structural and relational embeddedness in the steel and semiconductor industries." Strategic Management Journal, 21, 369-386. 
Schwarz, A., Mehta, M., Johnson, N., and Chin, W. (2007). "Understanding frameworks and reviews: a commentary to assist us in moving our field forward by analysing our past." ACM SIGMIS Database, 38(3), 29-50.

Shaw, W. (2002). Engineering management in our modern age. In IEEE International Engineering management conference, Cambridge University, UK, 2002.

Shokri, A., Waring, T., and Nabhani, F. (2016). "Investigating the readiness of people in manufacturing SMEs to embark on Lean Six Sigma projects: An empirical study in the German manufacturing sector.” International Journal of Operations \& Production Management, 36(8), 850-878.

Simsek, Z. (2009). “Organizational ambidexterity: towards a multilevel understanding." Journal of Management Studies, 46, 597-624.

Simsek, Z., Heavey, C., Veiga, J., and Souder, D. (2009). “A typology for aligning organizational ambidexterity's conceptualizations, antecedents, and outcomes.” Journal of Management Studies, $46,864-894$.

Smith, W., and Tushman, M. (2005). "Managing strategic contradictions: a top management model for managing innovation streams." Organization Science, 16, 522-36.

Stingl, V., and Geraldi, J. (2017). "Errors, lies and misunderstandings: Systematic review on behavioural decision making in projects.” International Journal of Project Management, 35(2), 121-135.

Sousa-Poza, A. and Kovacic, S. (2008). "Research agenda for complex situations." Engineering Management Journal, 20(4), 32-39.

Swart, J., Turner, N., Van Rossenberg, Y., and Kinnie, N. (2016). "Who does what in enabling ambidexterity? Individual Actions and HRM practices." International Journal of Human Resource Management, doi.org/10.1080/09585192.2016.1254106, 1-28.

Thomé, A., Scavarda, L., and Scavarda, A. (2016). "Conducting systematic literature review in operations management." Production Planning \& Control, 27(5), 408-420.

Thorpe, T. and Mead, S. (2001). "Project-specific web sites: Friend or foe?." ASCE Journal of Construction Engineering and Management, 127(5), 406-413.

Tiwana, A. (2010). "Systems development ambidexterity: explaining the complementary and substitutive roles of formal and informal controls." Journal of Management Information Systems, 27, 87-126.

Tranfield, D., Denyer, D., and Smart, P. (2003). "Towards a methodology for developing evidenceinformed management knowledge by means of systematic review." British Journal of Management, 14,207-222. 
Turner, N., and Lee-Kelley, L. (2013). "Unpacking the theory on ambidexterity: An illustrative case on the managerial architectures, mechanisms and dynamics." Management Learning, 44(2), 179196.

Turner, N., Swart, J., and Maylor, H. (2013a). "Mechanisms for managing ambidexterity: A review and research agenda." International Journal of Management Reviews, 15(3), 317-332.

Turner, N., Maylor, H., and Swart, J. (2013b). “Ambidexterity in managing business projects -an intellectual capital perspective." International Journal of Managing Projects in Business, 6(2), 379-389.

Turner, N., Maylor, H., Lee-Kelley, L., Brady, T., Kutsch, E., and Carver, S. (2014). “Ambidexterity and knowledge strategy in major projects: A framework and illustrative case study." Project Management Journal, 45(5), 44-55.

Turner, N., Maylor, H., and Swart, J. (2015). “Ambidexterity in projects: An intellectual capital perspective.” International Journal of Project Management, 33(1), 177-188.

Turner, N., Swart, J., Maylor, H., and Antonacopoulou, E. (2016). "Making it happen: How managerial actions enable project-based ambidexterity." Management Learning, 47(2), 199-222.

Tushman, M., and O'Reilly, C. (1996). “Ambidextrous organizations: Managing evolutionary and revolutionary change." California Management Review, 38, 8-30.

Tushman, M. and Euchner, J. (2015). "The challenges of ambidextrous leadership." ResearchTechnology Management, 58(3), 16-20.

Vits, J., and Gelders, L. (2002). "Performance improvement theory.” International Journal of Production Economics, 77(3), 285-298.

Voss, G., and Voss, Z. (2013). "Strategic ambidexterity in small and medium sized enterprises: Implementing exploration and exploitation in product and market domains." Organization Science, 24(5), 1459-1477.

Wei, Z., Zhao, J., and Zhang, C. (2014). "Organizational ambidexterity, market orientation, and firm performance.” Journal of Engineering and Technology Management, 33, 134-153.

Xiao, Y., and Watson, M. (2017). “Guidance on Conducting a Systematic Literature Review.” Journal of Planning Education and Research, p.0739456X17723971.

Xue, X., Shen, Q. and Ren, Z. (2010). "Critical review of collaborative working in construction projects: Business environment and human behaviours.” ASCE Journal of Management in Engineering, 26(4), 196-208. 
Zahra, S., and Das, S. (1993). "Innovation strategy and financial performance in manufacturing companies: An empirical analysis." Production Operations Management, 2, 15-37.

Zang, J., and Li, Y. (2017). "Technology capabilities, marketing capabilities and innovation ambidexterity." Technology Analysis and Strategic Management, 29(1), 23-37.

Zimmermann, A., Raisch, S., and Birkinshaw, J. (2015). "How is ambidexterity initiated? The emergent charter definition process." Organization Science, 26(4), 1119-1139.

Zimmermann, A., Raisch, S. and Cardinal, L. (2018). "Managing persistent tensions on the frontline: A configurational perspective on ambidexterity.” Journal of Management Studies, 55(5), 739-769. 
Table 1. Number of publications by each refining step

\begin{tabular}{|l|l|r|r|r|r|r|r|}
\hline Search option & Database/journal & Step 1 & Step 2 & Step 3 & Step 4 & Step 5 & Step 6 \\
\hline "ambidexterity" & EBSCO & 1052 & & & & & \\
\cline { 1 - 3 } "ambidextrous" & JSTOR & 408 & 700 & 46 & 74 & 45 & 21 \\
\hline "ambidex" and/or & OS, JOM, AOM & 17 & & & & & \\
\hline
\end{tabular}


Table 2. Analysis of ambidexterity levels

\begin{tabular}{|c|c|c|c|c|c|c|c|}
\hline Key publications & Motivation of the study & Industry & Method & Strategic level & Project level & Operations level & Individual level \\
\hline $\begin{array}{l}\text { Matthews et al. } \\
\text { (2015) }\end{array}$ & $\begin{array}{l}\text { Explores process } \\
\text { improvement through the } \\
\text { theoretical lens of } \\
\text { organizational } \\
\text { ambidexterity. }\end{array}$ & $\begin{array}{l}\text { Building } \\
\text { contractor } \\
\text { Engineering } \\
\text { consultancy } \\
\text { Management } \\
\text { consultancy } \\
\text { Telecom } \\
\text { firms. }\end{array}$ & Qualitative & N/A & N/A & $\begin{array}{l}\text { Process control } \\
\text { versus process } \\
\text { innovation. } \\
\text { Operational } \\
\text { process } \\
\text { improvement. }\end{array}$ & N/A \\
\hline $\begin{array}{l}\text { Jansen et al. } \\
\text { (2012) }\end{array}$ & $\begin{array}{l}\text { Examines the effect of } \\
\text { unit-level ambidexterity } \\
\text { on performance taking } \\
\text { decentralization of multi- } \\
\text { units, their resource } \\
\text { dependence and } \\
\text { munificence into account. }\end{array}$ & $\begin{array}{l}\text { Financial } \\
\text { services }\end{array}$ & Quantitative & $\begin{array}{l}\text { Organizational/ } \\
\text { strategic level } \\
\text { decentralization } \\
\text { of sub-units } \\
\text { and their } \\
\text { resource } \\
\text { dependence fall } \\
\text { under strategic } \\
\text { decisions of the } \\
\text { organization. }\end{array}$ & N/A & N/A & N/A \\
\hline $\begin{array}{l}\text { Chandrasekaran } \\
\text { et al. (2012) }\end{array}$ & $\begin{array}{l}\text { Explores ambidexterity as } \\
\text { a competence that resides } \\
\text { at different organisational } \\
\text { levels. }\end{array}$ & $\begin{array}{l}\text { Research and } \\
\text { Development } \\
\text { (R\&D) } \\
\text { projects and } \\
\text { high tech } \\
\text { business. }\end{array}$ & Quantitative & $\begin{array}{l}\text { The initial } \\
\text { decision of } \\
\text { exploitation or } \\
\text { exploration } \\
\text { cascades from a } \\
\text { strategic } \\
\text { decision } \\
\text { initiated by } \\
\text { senior } \\
\text { leadership. }\end{array}$ & $\begin{array}{l}\text { Two types of } \\
\text { projects had been } \\
\text { explored for fit to } \\
\text { ambidexterity; } \\
\text { exploratory and } \\
\text { exploitative } \\
\text { types. Incentives } \\
\text { are provided to } \\
\text { see balance } \\
\text { between these } \\
\text { projects through. }\end{array}$ & $\mathrm{N} / \mathrm{A}$ & N/A \\
\hline $\begin{array}{l}\text { Gibson and } \\
\text { Birkinshaw } \\
\text { (2004) }\end{array}$ & $\begin{array}{l}\text { Promotes the notion that } \\
\text { contextual ambidexterity } \\
\text { mediates behavioural } \\
\text { elements in the } \\
\text { organization }\end{array}$ & General & Quantitative & N/A & N/A & N/A & $\begin{array}{l}\text { Contextual } \\
\text { ambidexterity is } \\
\text { achieved by } \\
\text { building a } \\
\text { context that } \\
\text { encourages } \\
\text { individuals to } \\
\text { make their own } \\
\text { judgment of how } \\
\text { to best divide } \\
\text { their time }\end{array}$ \\
\hline
\end{tabular}




\begin{tabular}{|c|c|c|c|c|c|c|c|}
\hline & & & & & & & $\begin{array}{l}\text { between } \\
\text { conflicting } \\
\text { demands. }\end{array}$ \\
\hline $\begin{array}{l}\text { Kortmann et al. } \\
2014\end{array}$ & $\begin{array}{l}\text { Explores the balancing } \\
\text { between operational } \\
\text { efficiency and strategic } \\
\text { effectiveness through the } \\
\text { use of the mediating role } \\
\text { of mass customization } \\
\text { (i.e. production) }\end{array}$ & Manufacturing & Quantitative & $\begin{array}{l}\text { Balance } \\
\text { between } \\
\text { strategic } \\
\text { flexibility at a } \\
\text { strategic level } \\
\text { and operational } \\
\text { efficiency at } \\
\text { operations } \\
\text { level. }\end{array}$ & N/A & $\begin{array}{l}\text { Balance between } \\
\text { strategic } \\
\text { flexibility at a } \\
\text { strategic level } \\
\text { and operational } \\
\text { efficiency at } \\
\text { operations level. }\end{array}$ & N/A \\
\hline $\begin{array}{l}\text { Aubry and Lievre } \\
\text { (2010) }\end{array}$ & $\begin{array}{l}\text { Examines the tensions } \\
\text { between different modes } \\
\text { of action that a project } \\
\text { manager uses throughout } \\
\text { a project }\end{array}$ & $\begin{array}{l}\text { Expedition } \\
\text { projects }\end{array}$ & Qualitative & N/A & N/A & N/A & $\begin{array}{l}\text { A project } \\
\text { manager is } \\
\text { caught in tension } \\
\text { between two } \\
\text { modes of actions. }\end{array}$ \\
\hline \multirow[t]{2}{*}{$\begin{array}{l}\text { Andriopoulos } \\
\text { and Lewis (2009) }\end{array}$} & \multirow{2}{*}{$\begin{array}{l}\text { Examines nested } \\
\text { paradoxes of innovation } \\
\text { that cover various levels } \\
\text { in the organization: } \\
\text { strategic, project and } \\
\text { individual }\end{array}$} & \multirow[t]{2}{*}{ Product design } & \multirow[t]{2}{*}{ Qualitative } & \multirow{2}{*}{$\begin{array}{l}\text { Applies } \\
\text { differentiation } \\
\text { and integration } \\
\text { techniques to } \\
\text { profits versus } \\
\text { breakthroughs. }\end{array}$} & $\begin{array}{l}\text { Leverages } \\
\text { synergies } \\
\text { between project } \\
\text { constraints and } \\
\text { takes emerging } \\
\text { possibilities into } \\
\text { account } \\
\end{array}$ & \multirow[t]{2}{*}{ N/A } & \multirow{2}{*}{$\begin{array}{l}\text { Passion versus } \\
\text { discipline during } \\
\text { delivery as } \\
\text { exhibited by } \\
\text { knowledge } \\
\text { workers. }\end{array}$} \\
\hline & & & & & $\begin{array}{l}\text { Loose coupling } \\
\text { versus tight } \\
\text { coupling with } \\
\text { client during } \\
\text { project delivery. }\end{array}$ & & \\
\hline $\begin{array}{l}\text { Pellegrinelli et } \\
\text { al. (2015) }\end{array}$ & $\begin{array}{l}\text { Explores complementary } \\
\text { roles of projects and } \\
\text { programs in providing } \\
\text { ambidexterity }\end{array}$ & Retail banking & Qualitative & N/A & $\begin{array}{l}\text { The } \\
\text { complimentary } \\
\text { use of projects } \\
\text { and programs } \\
\text { produce } \\
\text { ambidexterity. }\end{array}$ & N/A & N/A \\
\hline $\begin{array}{l}\text { Jansen et al. } \\
\text { (2005) }\end{array}$ & $\begin{array}{l}\text { Undertakes a study } \\
\text { environmental and } \\
\text { organizational antecedents } \\
\text { and their effects on } \\
\text { ambidexterity }\end{array}$ & $\begin{array}{l}\text { Financial } \\
\text { services }\end{array}$ & Quantitative & N/A & N/A & $\begin{array}{l}\text { Ambidextrous } \\
\text { units are } \\
\text { characterized } \\
\text { with } \\
\text { decentralization } \\
\text { and formalization } \\
\text { of rules. }\end{array}$ & $\begin{array}{l}\text { Ambidextrous } \\
\text { units are } \\
\text { characterized by } \\
\text { individuals' } \\
\text { connectedness. }\end{array}$ \\
\hline
\end{tabular}




\begin{tabular}{|c|c|c|c|c|c|c|c|}
\hline Cao et al. (2009) & $\begin{array}{l}\text { Examines how to } \\
\text { operationalize } \\
\text { ambidexterious } \\
\text { improvements and how } \\
\text { they are applied in a } \\
\text { balanced or combined } \\
\text { mode }\end{array}$ & High tech & Quantitative & $\mathrm{N} / \mathrm{A}$ & $\mathrm{N} / \mathrm{A}$ & $\begin{array}{l}\text { The allocation of } \\
\text { resources on } \\
\text { exploitation or } \\
\text { exploration } \\
\text { activities is } \\
\text { dependent on the } \\
\text { way of how } \\
\text { ambidexterity is } \\
\text { being } \\
\text { operationalized. }\end{array}$ & N/A \\
\hline $\begin{array}{l}\text { Turner et al. } \\
\text { (2015) }\end{array}$ & $\begin{array}{l}\text { To study the use of } \\
\text { intellectual capital and } \\
\text { means of achieving } \\
\text { ambidexterity }\end{array}$ & $\begin{array}{l}\text { Technology } \\
\text { projects }\end{array}$ & Qualitative & $\mathrm{N} / \mathrm{A}$ & $\begin{array}{l}\text { Project based } \\
\text { working is } \\
\text { dominant work } \\
\text { in contemporary } \\
\text { organizations and } \\
\text { it relies heavily } \\
\text { on exploitation } \\
\text { and exploration. }\end{array}$ & N/A & N/A \\
\hline $\begin{array}{l}\text { Bednarek et al. } \\
\text { (2016) }\end{array}$ & $\begin{array}{l}\text { To explore the use of } \\
\text { dynamic client portfolio } \\
\text { as source of ambidexterity }\end{array}$ & $\begin{array}{l}\text { Global } \\
\text { reinsurance } \\
\text { industry }\end{array}$ & Qualitative & $\begin{array}{l}\text { The selection } \\
\text { of clients is a } \\
\text { strategic } \\
\text { decision and is } \\
\text { very relevant to } \\
\text { selecting the } \\
\text { portfolio of } \\
\text { projects for the } \\
\text { organization. }\end{array}$ & $\begin{array}{l}\text { The selection of } \\
\text { clients is a } \\
\text { strategic decision } \\
\text { and is very } \\
\text { relevant to } \\
\text { selecting the } \\
\text { portfolio of } \\
\text { projects for the } \\
\text { organization. }\end{array}$ & N/A & N/A \\
\hline $\begin{array}{l}\text { Voss and Voss } \\
\text { (2013) }\end{array}$ & $\begin{array}{l}\text { To examine ambidexterity } \\
\text { within and across } \\
\text { organizational functions } \\
\text { and test the effect on } \\
\text { performance }\end{array}$ & Service sector & Quantitative & $\mathrm{N} / \mathrm{A}$ & $\mathrm{N} / \mathrm{A}$ & $\begin{array}{l}\text { Ambidexterity is } \\
\text { theorized and } \\
\text { tested at a } \\
\text { functional level: } \\
\text { product and } \\
\text { market. }\end{array}$ & N/A \\
\hline $\begin{array}{l}\text { Mom et al. } \\
\text { (2007) }\end{array}$ & $\begin{array}{l}\text { This study tests the } \\
\text { influence of managers' } \\
\text { knowledge flow direction } \\
\text { on ambidexterity }\end{array}$ & $\begin{array}{l}\text { Electronic } \\
\text { industry }\end{array}$ & Quantitative & N/A & $\mathrm{N} / \mathrm{A}$ & N/A & $\begin{array}{l}\text { Managers' } \\
\text { communication } \\
\text { means has an } \\
\text { effect on } \\
\text { ambidexterity. }\end{array}$ \\
\hline
\end{tabular}




\begin{tabular}{|c|c|c|c|c|c|c|c|}
\hline & & & & & & $\begin{array}{l}\text { operational } \\
\text { decision. }\end{array}$ & \\
\hline $\begin{array}{l}\text { Turner et al. } \\
\text { (2014) }\end{array}$ & $\begin{array}{l}\text { To develop a framework } \\
\text { to capture knowledge } \\
\text { requirements of projects } \\
\text { at multiple organizational } \\
\text { levels. }\end{array}$ & Telecomm. & Qualitative & $\mathrm{N} / \mathrm{A}$ & $\begin{array}{l}\text { Capture } \\
\text { knowledge at a } \\
\text { project level to } \\
\text { build exploitation } \\
\text { and exploration } \\
\text { capabilities. }\end{array}$ & N/A & N/A \\
\hline $\begin{array}{l}\text { Lubatkin et al. } \\
\text { (2006) }\end{array}$ & $\begin{array}{l}\text { To study how top } \\
\text { management team } \\
\text { behavioural integration } \\
\text { affects organizational- } \\
\text { level ambidexterity. }\end{array}$ & $\begin{array}{l}\text { Small to } \\
\text { medium sized } \\
\text { firms }\end{array}$ & Quantitative & $\mathrm{N} / \mathrm{A}$ & N/A & N/A & $\begin{array}{l}\text { The behavioural } \\
\text { integration of } \\
\text { Top Management } \\
\text { Teams (TMT) } \\
\text { has a major } \\
\text { effect on } \\
\text { ambidexterity. }\end{array}$ \\
\hline $\begin{array}{l}\text { He and Wong } \\
\text { (2004) }\end{array}$ & $\begin{array}{l}\text { To examine how } \\
\text { exploitation and } \\
\text { exploration can jointly } \\
\text { influence performance in } \\
\text { the context of } \\
\text { technological innovation. }\end{array}$ & Manufacturing & Quantitative & N/A & N/A & $\begin{array}{l}\text { Exploitation and } \\
\text { exploration } \\
\text { requires different } \\
\text { structures, } \\
\text { process, } \\
\text { strategies and } \\
\text { capabilities. }\end{array}$ & N/A \\
\hline Wei et al. (2014) & $\begin{array}{l}\text { To examine the effect of } \\
\text { exploitation and } \\
\text { exploration activities on } \\
\text { firms with proactive and } \\
\text { responsive market } \\
\text { orientation. }\end{array}$ & General & Quantitative & $\begin{array}{l}\text { Studies the role } \\
\text { of strategic } \\
\text { orientation of } \\
\text { market } \\
\text { approach on } \\
\text { ambidexterity. }\end{array}$ & N/A & N/A & N/A \\
\hline $\begin{array}{l}\text { Turner et al. } \\
(2013 a)\end{array}$ & $\begin{array}{l}\text { To study the use of } \\
\text { intellectual capital and } \\
\text { means of achieving } \\
\text { ambidexterity }\end{array}$ & Projects & Qualitative & NA & $\begin{array}{l}\text { This study } \\
\text { mainly addresses } \\
\text { IC in technology } \\
\text { projects }\end{array}$ & NA & NA \\
\hline
\end{tabular}


Table 3. Analysis - Attributes and identifiers used to define "Dimensions"

\begin{tabular}{|c|c|}
\hline Dimensions & Attributes and/or identifiers \\
\hline \multirow[t]{2}{*}{ Knowledge } & $\begin{array}{l}\text { Develop, diffuse, codify, assimilate and share knowledge (Rowley et al., 2000; Jansen et al., } \\
\text { 2005; Jansen et al., 2006; Lubatkin et al., 2006; Mom et al., 2007; Im and Rai, 2008; Cao et } \\
\text { al., 2009; Jansen et al., 2012; Eriksson, 2013; Turner et al., 2014; Wei et al., 2014; Matthews } \\
\text { et al., 2015; Bednarek et al., 2016) }\end{array}$ \\
\hline & $\begin{array}{l}\text { Pursue, obtain and manage innovation (Jansen et al., 2006; Cao et al., 2009; Andriopoulos } \\
\text { and Lewis, 2009; Jansen et al., 2012; Matthews et al., 2015) }\end{array}$ \\
\hline \multirow{8}{*}{ Behaviour } & Cognitive use for activity assigning (Kaplan, 2008; Chandrasekaran et al., 2012) \\
\hline & Individual judgement of conflicting demands (Gibson and Birkinshaw, 2004) \\
\hline & Stretch and discipline and support and trust (Gibson and Birkinshaw, 2004) \\
\hline & Alignment and adaptability (Gibson and Birkinshaw, 2004) \\
\hline & Cognitive tension between action modes (Aubry and Lievre, 2010) \\
\hline & Discipline versus passion during delivery (Andriopoulos and Lewis, 2009) \\
\hline & $\begin{array}{l}\text { Defenders versus prospectors role (Auh and Menguc, 2005); team composition and company } \\
\text { affiliation (Beckman, 2006) }\end{array}$ \\
\hline & Production of radical innovation (O'Connor and DeMartino, 2006). \\
\hline \multirow{5}{*}{ Technology } & R\&D and technology projects (Chandrasekaran et al., 2012) \\
\hline & Mass customization and production impact upon efficiency (Kortmann et al., 2014) \\
\hline & Innovation in New Product Designs (Andriopoulos and Lewis, 2009) \\
\hline & Developing new product technologies and capabilities (Voss and Voss, 2013) \\
\hline & $\begin{array}{l}\text { Internal versus external technology sourcing (Rothaermel and Alexandre, 2009); and } \\
\text { technological innovation (He and Wong, 2004). }\end{array}$ \\
\hline \multirow{9}{*}{ Process } & Process improvement versus process control (Matthews et al., 2015) \\
\hline & Operational efficiency versus strategic flexibility (Kortmann et al., 2014) \\
\hline & $\begin{array}{l}\text { Coupling during delivery (Andriopoulos and Lewis, 2009); Process oriented approach to } \\
\text { flexibility and change (Pellegrinelli et al., 2015); }\end{array}$ \\
\hline & Process structures (Rowley et al., 2000; Jansen et al., 2005); \\
\hline & Knowledge attainment through client portfolios (Bednarek et al., 2016); \\
\hline & Process innovation (Zahra and Das, 1993); \\
\hline & Production processes for flexibility and efficiency (Adler et al., 1999) \\
\hline & Autonomous strategic processes (Burgelman, 1991, 2002) \\
\hline & Sensing opportunities and routines (O'Reilly and Tushman, 2011,2013). \\
\hline
\end{tabular}


Table 4. Analysis - Attributes and identifiers used to define "Mechanisms"

\begin{tabular}{|c|c|}
\hline Mechanisms & Attributes and/or identifiers \\
\hline \multirow{17}{*}{ Structural } & Organizational structure (Jansen et al., 2012) \\
\hline & Resource dependence (Jansen et al., 2012) \\
\hline & Structural separation (Chandrasekaran et al., 2012) \\
\hline & Mass customization (Kortmann et al., 2014) \\
\hline & Innovation partitioning (Kortmann et al., 2014) \\
\hline & Complementary tactics across all structural levels (Andriopoulos and Lewis, 2009) \\
\hline & Structural balancing (Pellegrinelli et al., 2015) \\
\hline & Portfolio management utilisation (Pellegrinelli et al., 2015); \\
\hline & Structural decentralization (Jansen et al., 2005) \\
\hline & Project activity balancing (Cao et al., 2009); \\
\hline & Structure selection (Turner et al., 2015) \\
\hline & Cross functional domain combination (Voss and Voss, 2013) \\
\hline & Organizational design (He and Wong, 2004) \\
\hline & Organizational domain separation (Lavie et al., 2009,2010) \\
\hline & Simultaneous structural utilisation (Bradach, 1997) \\
\hline & Tightly coupled sub-units (Benner and Tushman, 2003) \\
\hline & Different operational approaches (Kaplan and Henderson, 2005). \\
\hline \multirow{6}{*}{ Learning } & Exploitative learning and reduction of process variation (Matthews et al., 2015) \\
\hline & Cross-resources learning enabled switching (Kortmann et al., 2014) \\
\hline & Emergent learning through adaptation (Aubry and Lievre, 2010) \\
\hline & Enhancing organizational absorptive capacity (Jansen et al. 2006; Andriopoulos and Lewis, 2009) \\
\hline & Execute projects with learning versus execution with efficiency (Edmonson, 2008; Turner et al., 2014) \\
\hline & Balancing existing versus new competencies (Danneels, 2002) \\
\hline \multirow{15}{*}{ Selection } & Procurement methodology selection (Eriksson, 2013) \\
\hline & Project team selection (Eriksson, 2013) \\
\hline & Incentive allocation (Chandrasekaran et al., 2012) \\
\hline & Adaptive allocation of resources to achieve strategic flexibility (Kortmann et al., 2014 \\
\hline & Employees" "enrichment" as innovation routes (Kortmann et al., 2014) \\
\hline & Resource allocation (Andriopoulos and Lewis, 2009) \\
\hline & Organisational size driven resource allocation (Cao et al., 2009) \\
\hline & Client portfolio selection (Bednarek et al., 2016) \\
\hline & Resources prioritisation (He and Wong, 2004) \\
\hline & Resources allocation through strategic orientation (Wei et al., 2014) \\
\hline & Source selection across organizational boundaries (Rosenkopf and Nerkar, 2001) \\
\hline & Knowledge capturing (Bednarek et al., 2016) \\
\hline & Internal versus external sourcing (Rothaermel and Alexandre, 2009) \\
\hline & Re-allocation of resources (O'Reilly and Tushman, 2011,2013) \\
\hline & Project type selection (Pellegrinelli et al., 2015) \\
\hline \multirow{9}{*}{ Communication } & Facilitated communication through structural decentralization/centralization (Eriksson, 2013) \\
\hline & Unit resource dependency (Jansen et al., 2012) \\
\hline & Downward communication (Chandrasekaran et al., 2012) \\
\hline & Adaptation of responsive behaviour (Gibson and Birkinshaw, 2004) \\
\hline & Employee interaction and knowledge flow (Jansen et al., 2005) \\
\hline & Social networks utilisation (Turner et al., 2015) \\
\hline & Communication flow and knowledge (Mom et al., 2007) \\
\hline & Knowledge flow and behaviour (Lubatkin et al., 2006) \\
\hline & Diversity (Simsek, 2009) \\
\hline
\end{tabular}


Table 5. Studies/articles used in Steps 5 \& 6 of the systematic review

\begin{tabular}{|c|c|c|c|c|}
\hline $\mathbf{S N}$ & Key publications & Title of the study & Publishing journal & $\begin{array}{l}\text { No. of citations } \\
\text { as of June } 2018\end{array}$ \\
\hline 1 & Matthews et al. (2015)* & $\begin{array}{l}\text { Organisational ambidexterity within process improvement: An } \\
\text { exploratory study of four project-oriented firms }\end{array}$ & $\begin{array}{l}\text { Journal of Manufacturing } \\
\text { Technology Management }\end{array}$ & 15 \\
\hline 2 & Jansen et al. (2012)* & $\begin{array}{l}\text { Ambidexterity and performance in multiunit contexts: Cross-level } \\
\text { moderating effects of structural and resource attributes }\end{array}$ & Strategic Management Journal & 191 \\
\hline 3 & $\begin{array}{l}\text { Chandrasekaran et al. } \\
(2012)^{*}\end{array}$ & $\begin{array}{l}\text { Antecedents to ambidexterity competency in high technology } \\
\text { organizations }\end{array}$ & $\begin{array}{l}\text { Journal of Operations } \\
\text { Management }\end{array}$ & 94 \\
\hline 4 & $\begin{array}{l}\text { Gibson and Birkinshaw } \\
\text { (2004)* }\end{array}$ & $\begin{array}{l}\text { The antecedents, consequences, and mediating role of organizational } \\
\text { ambidexterity }\end{array}$ & Academy of Management Journal & 2890 \\
\hline 5 & Kortmann et al. (2014)* & $\begin{array}{l}\text { Linking strategic flexibility and operational efficiency: The mediating } \\
\text { role of ambidextrous operational capabilities }\end{array}$ & $\begin{array}{l}\text { Journal of Operations } \\
\text { Management }\end{array}$ & 71 \\
\hline 6 & $\begin{array}{l}\text { Aubry and Lievre } \\
(2010)^{*}\end{array}$ & $\begin{array}{l}\text { Ambidexterity as a competence of project leaders: A case study from two } \\
\text { polar expeditions }\end{array}$ & Project Management Journal & 36 \\
\hline 7 & $\begin{array}{l}\text { Andriopoulos and Lewis } \\
\text { (2009)* }\end{array}$ & $\begin{array}{l}\text { Exploitation-exploration tensions and organizational ambidexterity: } \\
\text { Managing paradoxes of innovation }\end{array}$ & Organization Science & 1136 \\
\hline 8 & $\begin{array}{l}\text { Pellegrinelli et al. } \\
(2015)^{*}\end{array}$ & $\begin{array}{l}\text { Facilitating organizational ambidexterity through the complementary use } \\
\text { of projects and programs }\end{array}$ & $\begin{array}{l}\text { International Journal of Project } \\
\text { Management }\end{array}$ & 29 \\
\hline 9 & Jansen et al. (2005)* & $\begin{array}{l}\text { Exploratory innovation, exploitative innovation, and ambidexterity: the } \\
\text { impact of environmental and organizational antecedents }\end{array}$ & Schmalenbach Business Review & 335 \\
\hline 10 & Cao et al. (2009)* & $\begin{array}{l}\text { Unpacking organizational ambidexterity: Dimensions, contingencies, and } \\
\text { synergistic effects }\end{array}$ & Organization Science & 756 \\
\hline 11 & Turner et al. (2015)* & Ambidexterity in projects: An intellectual capital perspective & $\begin{array}{l}\text { International Journal of Project } \\
\text { Management }\end{array}$ & 29 \\
\hline 12 & Bednarek et al. (2016)* & $\begin{array}{l}\text { Dynamic client portfolios as sources of ambidexterity: Exploration and } \\
\text { exploitation within and across client relationships }\end{array}$ & Long Range Planning & 17 \\
\hline 13 & Voss and Voss (2013)* & $\begin{array}{l}\text { Strategic ambidexterity in small and medium sized enterprises: } \\
\text { Implementing exploration and exploitation in product and market } \\
\text { domains }\end{array}$ & Organization Science & 144 \\
\hline 14 & Mom et al. (2007)* & $\begin{array}{l}\text { Investigating managers' exploration and exploitation activities: The } \\
\text { influence of top-down, bottom-up, and horizontal knowledge inflows }\end{array}$ & Journal of Management Studies & 424 \\
\hline
\end{tabular}




\begin{tabular}{|c|c|c|c|c|}
\hline 15 & $\begin{array}{l}\text { Rothaermel and } \\
\text { Alexandre (2009)* }\end{array}$ & $\begin{array}{l}\text { Ambidexterity in technology sourcing: The moderating role of absorptive } \\
\text { capacity }\end{array}$ & Organization Science & 677 \\
\hline 16 & Turner et al. (2014)* & $\begin{array}{l}\text { Ambidexterity and knowledge strategy in major projects: A framework } \\
\text { and illustrative case study }\end{array}$ & Project Management Journal & 18 \\
\hline 17 & Lubatkin et al. (2006)* & $\begin{array}{l}\text { Ambidexterity and performance in small- to medium-sized firms: the } \\
\text { pivotal role of top management team behavioural integration }\end{array}$ & Journal of Management & 1359 \\
\hline 18 & He and Wong (2004)* & $\begin{array}{l}\text { Exploration vs. exploitation: an empirical test of the ambidexterity } \\
\text { hypothesis }\end{array}$ & Organization Science & 3009 \\
\hline 19 & Wei et al. (2014)* & Organizational ambidexterity, market orientation, and firm performance & $\begin{array}{l}\text { Journal of Engineering and } \\
\text { Technology Management }\end{array}$ & 32 \\
\hline 20 & Turner et al. (2013a)* & Mechanisms for managing ambidexterity: A review and research agenda & $\begin{array}{l}\text { International Journal of } \\
\text { Management Reviews }\end{array}$ & 214 \\
\hline 21 & Turner et al. $(2013 b)^{*}$ & $\begin{array}{l}\text { Ambidexterity in managing business projects -an intellectual capital } \\
\text { perspective }\end{array}$ & $\begin{array}{l}\text { International Journal of Managing } \\
\text { Projects in Business }\end{array}$ & 8 \\
\hline 22 & Rowely et al. (2000) & $\begin{array}{l}\text { Redundant governance structures: An analysis of structural and relational } \\
\text { embeddedness in the steel and semiconductor industries }\end{array}$ & Strategic Management Journal & 2332 \\
\hline 23 & Jansen et al. (2005) & $\begin{array}{l}\text { Exploratory innovation, exploitative innovation, and ambidexterity: the } \\
\text { impact of environmental and organizational antecedents }\end{array}$ & Schmalenbach Business Review & 335 \\
\hline 24 & Jansen et al. (2006) & $\begin{array}{l}\text { Explorative Innovation, Exploitative Innovation and Performance: Effects } \\
\text { of Organizational Antecedents and Environmental Moderators }\end{array}$ & Management Science & 2260 \\
\hline 25 & Im \& Rai (2008) & $\begin{array}{l}\text { Knowledge sharing ambidexterity in long-term interorganizational } \\
\text { relationships }\end{array}$ & Management Science & 378 \\
\hline 26 & Eriksson (2013) & $\begin{array}{l}\text { Exploration and exploitation in project-based organizations: } \\
\text { Development and diffusion of knowledge at different organizational } \\
\text { levels in construction companies }\end{array}$ & $\begin{array}{l}\text { International Journal of Project } \\
\text { Management }\end{array}$ & 112 \\
\hline 27 & Kaplan (2008) & Framing contests: Strategy making under uncertainty. & Organization Science & 651 \\
\hline 28 & Auh \& Menguc (2005) & $\begin{array}{l}\text { Balancing exploration and exploitation: The moderating role of } \\
\text { competitive intensity }\end{array}$ & Journal of Business Research & 608 \\
\hline 29 & Beckman (2006) & The influence of founding team company affiliations on firm behavior & Academy of Management Journal & 666 \\
\hline
\end{tabular}




\begin{tabular}{|c|c|c|c|c|}
\hline 31 & Zahra \& Das(1993) & $\begin{array}{l}\text { Innovation strategy and financial performance in manufacturing } \\
\text { companies: An empirical analysis }\end{array}$ & $\begin{array}{l}\text { Production Operations } \\
\text { Managemen }\end{array}$ & 192 \\
\hline 32 & Adler et al. (1999) & $\begin{array}{l}\text { Flexibility versus efficiency: A case study of model changeovers in the } \\
\text { Toyota production systems }\end{array}$ & Organization Science & 1560 \\
\hline 33 & Burgelman (1991) & $\begin{array}{l}\text { Intraorganizational ecology of strategy making and organizational } \\
\text { adaptation: Theory and field research }\end{array}$ & Organization Science & 1735 \\
\hline 34 & Burgelman (2002) & Strategy as vector and the inertia of coevolutionary lock-in & Administrative Science Quarterly & 876 \\
\hline 35 & $\begin{array}{l}\text { O'Reilly \& Tushman } \\
\text { (2011) }\end{array}$ & $\begin{array}{l}\text { Organizational ambidexterity in action: how managers explore and } \\
\text { exploit }\end{array}$ & California Management Review & 334 \\
\hline 36 & \begin{tabular}{|l|} 
O'Reilly \& Tushman \\
(2013)
\end{tabular} & Organizational ambidexterity: Past, present, and future & $\begin{array}{l}\text { Academy of Management } \\
\text { Perspectives }\end{array}$ & 697 \\
\hline 37 & Lavie et al. (2009) & $\begin{array}{l}\text { The performance effects of balancing exploration and exploitation within } \\
\text { and across alliance domains }\end{array}$ & $\begin{array}{l}\text { Paper presented at the Academy of } \\
\text { Management Best Paper } \\
\text { Proceedings, Chicago, IL. }\end{array}$ & 21 \\
\hline 38 & Lavie et al. (2010) & Exploration and exploitation within and across organizations & $\begin{array}{l}\text { The Academy of Management } \\
\text { Annals }\end{array}$ & 843 \\
\hline 39 & Bradach (1997) & Using the plural form in the management of restaurant chains & Administrative Science Quarterly & 823 \\
\hline 40 & $\begin{array}{l}\text { Benner \& Tushman } \\
\text { (2003) }\end{array}$ & $\begin{array}{l}\text { Exploitation, exploration, and process management: The productivity } \\
\text { dilemma revisited }\end{array}$ & Academy of Management Review & 3857 \\
\hline 41 & $\begin{array}{l}\text { Kaplan \& Henderson } \\
(2005)\end{array}$ & $\begin{array}{l}\text { Inertia and incentives: Bridging organizational economics and } \\
\text { organizational theory }\end{array}$ & Organization Science & 257 \\
\hline 42 & Edmondson (2008) & The competitive imperative of learning & Harvard Business Review & 313 \\
\hline 43 & Danneels (2002) & The dynamics of product innovation and firm competences & Strategic management journal & 2424 \\
\hline 44 & $\begin{array}{l}\text { Rosenkopf \& } \\
\text { Nerkar(2001) }\end{array}$ & $\begin{array}{l}\text { Beyond local search: Boundary-spanning, exploration, and impact in the } \\
\text { optical disk industry }\end{array}$ & Strategic Management Journal & 2318 \\
\hline 45 & Simsek (2009) & Organizational ambidexterity: towards a multilevel understanding & Journal of Management Studies & 549 \\
\hline
\end{tabular}


Table 6. Analysis between levels and dimensions of ambidexterity

\begin{tabular}{|c|c|c|c|c|}
\hline Dimension & Knowledge & Behaviour & Technology & Process \\
\hline Strategic & $\begin{array}{l}\text { Sharing across strategic units (Jansen et al. } \\
\text { 2012); benefit from strategically selected } \\
\text { client portfolios (Bednarek et al. 2016); } \\
\text { strategic orientation and market knowledge } \\
\text { (Wei et al. 2014) }\end{array}$ & $\begin{array}{l}\text { Cognition helps decide strategies } \\
\text { (Chandrasekaran et al. 2012); } \\
\text { leadership facilitates managing } \\
\text { strategic contradictions (Smith and } \\
\text { Tushman 2005) }\end{array}$ & $\begin{array}{l}\text { Decision on technology is strategized at } \\
\text { the top level (Chandrasekaran et al. } \\
\text { 2012) }\end{array}$ & $\begin{array}{l}\text { Operational efficiency versus } \\
\text { strategic flexibility (Kortmann et } \\
\text { al. 2014); Organisations exercise } \\
\text { simultaneous autonomous } \\
\text { strategic processes (Burgelman } \\
\text { 2002) }\end{array}$ \\
\hline Projects & $\begin{array}{l}\text { Benefit from knowledge that comes from a } \\
\text { strategically selected portfolio of projects and } \\
\text { clients (Bednarek et al. 2016); diffusion of } \\
\text { knowledge for R\&D activities (Eriksson } \\
\text { 2013); the use of intellectual capital (IC) to } \\
\text { communicate knowledge within projects } \\
\text { (Turner et al. 2015); projects are knowledge- } \\
\text { based activities (Turner et al. 2014) }\end{array}$ & $\begin{array}{l}\text { Project manager's behaviour in } \\
\text { project delivery, the use of } \\
\text { rationalization versus efficiency } \\
\text { during delivery (Aubry and Lievre } \\
\text { 2010) }\end{array}$ & $\begin{array}{l}\text { Exploratory and exploitative } \\
\text { technology projects are incentivized for } \\
\text { better performance (Chandrasekaran et } \\
\text { al. 2012); technological innovation } \\
\text { projects (He and Wong 2004) }\end{array}$ & $\begin{array}{l}\text { Projects provide control and } \\
\text { serve as a learning platform (Vits } \\
\text { and Gelders 2002); coupling } \\
\text { delivery processes (Andriopoulos } \\
\text { and Lewis 2009); process control } \\
\text { and flexibility (Pellegrinelli et al. } \\
\text { 2015) }\end{array}$ \\
\hline Operations & $\begin{array}{l}\text { Codification of knowledge provides control - } \\
\text { exploitation (Matthews et al. 2015); } \\
\text { exploitation and exploration build absorptive } \\
\text { capacity to make the organization accept new } \\
\text { knowledge (Cao et al. 2009) }\end{array}$ & N/A & $\begin{array}{l}\text { Codify expertise (exploration) and } \\
\text { codify knowledge (exploitation) } \\
\text { (Matthews et al. 2015); mass } \\
\text { customization, operation and } \\
\text { technology of production (Kortmann et } \\
\text { al. 2014); focus on new product } \\
\text { development versus improve current } \\
\text { products (Voss and Voss 2013); decide } \\
\text { on the source of technology - internal } \\
\text { or external (Rothaermel and Alexandre } \\
\text { 2009); }\end{array}$ & $\begin{array}{l}\text { Process improvements and } \\
\text { control (Matthews et al. 2015); } \\
\text { codification of processes } \\
\text { (Matthews et al. 2015); } \\
\text { decentralization and rule } \\
\text { formalisation (Jansen et al. 2005) }\end{array}$ \\
\hline Individual & $\begin{array}{l}\text { Connectedness and social interaction for } \\
\text { better knowledge flow (Jansen et al. 2005); } \\
\text { flow of knowledge has an effect on } \\
\text { ambidexterity (Mom et al. 2007); knowledge } \\
\text { sharing and integration between TMTs } \\
\text { (Lubatkin et al. 2006) }\end{array}$ & $\begin{array}{l}\text { Individual behavioural activities lead } \\
\text { to achieving contextual ambidexterity } \\
\text { (Gibson and Birkinshaw 2004); two } \\
\text { modes of cognitive actions in tension } \\
\text { (Aubry and Lievre 2010); passion } \\
\text { versus discipline in delivery } \\
\text { (Andriopoulos and Lewis 2009) }\end{array}$ & N/A & N/A \\
\hline
\end{tabular}


Table 7. Analysis between dimensions and mechanisms of ambidexterity

\begin{tabular}{|c|c|c|c|c|}
\hline & Structural & Learning & Selection & Communication \\
\hline Knowledge & $\begin{array}{l}\text { The use of complementary } \\
\text { tactics (Andriopoulos and } \\
\text { Lewis 2009); the use of various } \\
\text { organizational structure such as } \\
\text { organic or mechanistic (Turner } \\
\text { et al. 2015) }\end{array}$ & $\begin{array}{l}\text { Interplay between exploitation or } \\
\text { exploration to build absorptive } \\
\text { capacity (Andriopoulos and Lewis } \\
\text { 2009); learning from clients: } \\
\text { nurturing, investigating, holding } \\
\text { and watching (Bednarek et al. } \\
\text { 2016); execution as learning } \\
\text { (Turner et al. 2014); classify new } \\
\text { projects based on existing } \\
\text { competencies versus new } \\
\text { competencies (Danneels 2002) }\end{array}$ & $\begin{array}{l}\text { Allocation of resources to exploratory } \\
\text { and exploitative tasks improves on the } \\
\text { absorptive capacity of the organization } \\
\text { (Cao et al. 2009); the selection of } \\
\text { clients' dynamic portfolios to obtain } \\
\text { new sources of knowledge (Bednarek et } \\
\text { al. 2016); resource allocation based on } \\
\text { knowledge about market and the } \\
\text { strategic orientation of the organization } \\
\text { (Wei et al. 2014) }\end{array}$ & $\begin{array}{l}\text { Knowledge sharing between TMTs } \\
\text { (Lubatkin et al. 2006 ); } \\
\text { flow/communication of knowledge } \\
\text { (Mom et al. 2007); decentralize } \\
\text { knowledge for diffusion (Eriksson, } \\
\text { 2013); resource dependence and } \\
\text { sharing knowledge through } \\
\text { communication across units (Jansen et } \\
\text { al. 2012); connectedness and social } \\
\text { interaction to share knowledge (Jansen } \\
\text { et al. 2005); the use of heavy social } \\
\text { networks (Turner et al. 2015) }\end{array}$ \\
\hline Behaviour & N/A & $\begin{array}{l}\text { Rationalization versus adaptation } \\
\text { for the situation in hand (Aubry and } \\
\text { Lievre 2010) }\end{array}$ & $\begin{array}{l}\text { Select behaviourally ambidextrous } \\
\text { employees during hiring process }\end{array}$ & $\begin{array}{l}\text { Communication from top management } \\
\text { that encourages employees' adaptation } \\
\text { to contextual ambidexterity (Gibson } \\
\text { and Birkinshaw 2004) }\end{array}$ \\
\hline Technology & $\begin{array}{l}\text { Project partitioning or } \\
\text { separation according to degree } \\
\text { of innovativeness (Kortmann et } \\
\text { al. 2014); complementary } \\
\text { tactics to gather various } \\
\text { technological aspects between } \\
\text { projects (Andriopoulos and } \\
\text { Lewis 2009); combining } \\
\text { exploratory and exploitative } \\
\text { product and market } \\
\text { development (Voss and Voss } \\
\text { 2013); organizational design for } \\
\text { ambidexterity (He and Wong } \\
\text { 2004) }\end{array}$ & $\begin{array}{l}\text { Resources capabilities of switching } \\
\text { between technologies and } \\
\text { technological projects (Kortmann et } \\
\text { al. 2014); classify new projects } \\
\text { based on existing competencies } \\
\text { versus new competencies (Danneels } \\
2002 \text { ) }\end{array}$ & $\begin{array}{l}\text { Select project team to facilitate } \\
\text { ambidexterity (Eriksson 2013); select } \\
\text { procurement methods to facilitate } \\
\text { ambidexterity (Eriksson 2013); } \\
\text { incentivize project teams to work on } \\
\text { exploratory/exploitative projects } \\
\text { (Chandrasekaran et al. 2012); select the } \\
\text { source of technology - internal/external } \\
\text { (Rothaermel and Alexandre 2009); } \\
\text { prioritize resources' allocation to } \\
\text { technological innovation (He and Wong } \\
\text { 2004); resources allocation to projects } \\
\text { portfolio (Andriopoulos and Lewis } \\
\text { 2009) }\end{array}$ & $\begin{array}{l}\text { Decisions of exploitation or } \\
\text { exploration cascades down and } \\
\text { communicated from top management } \\
\text { (Chandrasekaran et al. 2012) }\end{array}$ \\
\hline Process & $\begin{array}{l}\text { Complementary tactics } \\
\text { (Andriopoulos and Lewis } \\
\text { 2009); the application of } \\
\text { portfolio management to } \\
\text { balance between projects and } \\
\text { the overarching program } \\
\text { (Pellegrinelli et al. 2015); } \\
\text { decentralization of processes } \\
\text { (Jansen et al. 2005) }\end{array}$ & $\begin{array}{l}\text { Learning through process } \\
\text { innovation versus learning through } \\
\text { process control (Matthews et al. } \\
\text { 2015); employees learnt capabilities } \\
\text { by switching (Kortmann et al. } \\
\text { 2014); classify new projects based } \\
\text { on existing competencies versus } \\
\text { new competencies (Danneels 2002) }\end{array}$ & $\begin{array}{l}\text { Resources allocation to projects } \\
\text { portfolio (Andriopoulos and Lewis } \\
\text { 2009); employees' enrichment } \\
\text { (Kortmann et al. 2014) }\end{array}$ & $\begin{array}{l}\text { Formalization of rules (Jansen et al. } \\
\text { 2005); communication processes } \\
\text { through decentralized structures } \\
\text { (Jansen et al. 2005) }\end{array}$ \\
\hline
\end{tabular}


Figure 1. Levels of ambidexterity, dimensions and mechanisms

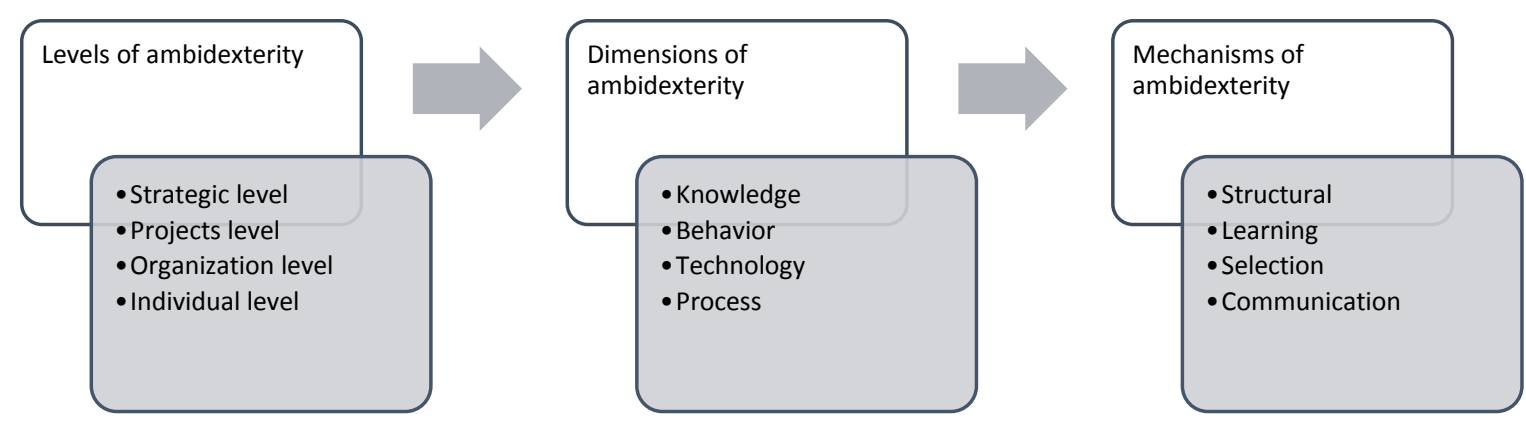

